\title{
ALKALINE COMPLEXES AS POTENTIAL AREAS FOR INSTALLATION OF REPOSITORIES OF NUCLEAR WASTE: CRETACEOUS INTRUSIONS IN BRAZIL
}

\author{
Mauro Cesar Geraldes ${ }^{1 *}$, Corbiniano Silva ${ }^{1}$, Ariadne Marra de Souza ${ }^{2}$, Miguel Angelo Mane ${ }^{1}$, Marcelo dos \\ Santos Salomão ${ }^{1}$, Elaine Alves dos Santos ${ }^{1}$, Armando Dias Tavares ${ }^{1}$, Daniel Adelino da Silva ${ }^{1}$, ANDERSON Costa \\ dos SANTos ${ }^{1}$, ANderson Dias CÉzAR ${ }^{3}$ AND Paula Maria Moura de Almeida ${ }^{3}$
}

1 Universidade do Estado do Rio de Janeiro - UERJ, Faculdade de Geologia, Av. São Francisco Xavier, 524, Maracanã. 20550-013 Rio de Janeiro, RJ, Brazil. geraldes@uerj.br, corbiniano@gmail.com, miguelmane@yahoo.com, salomao.mss@gmail.com, elainealves1301@gmail.com, tavares@uerj.br, adelinogeologia@yahoo.com.br, costasantos@gmail.com

2 Universidade Federal do Espírito Santo - UFES, Av. Fernando Ferrari, 514 - Goiabeiras, Vitória - ES, 29075-910, Brazil. ariadne_marra@oi.com.br

3. Universidade Castelo Branco, R. Gonçalves Dias, 56 - Centro, Rio de Janeiro - RJ, 20050-030, Brazil. adcezar@castelobranco.br, paulamaria@castelobranco.br

* Corresponding author, geraldes@uerj.br

Received on 24 June 2017

Received in revised form on 9 August 2017

Accepted on 14 August 2017

Editor:

Maria Virginia Alves Martins, Universidade do Estado do Rio de Janeiro, Brazil

\section{Abstract}

Brazil initiated its nuclear program in the decade of 70 with the installation of the Thermonuclear Plant Angra I. The implantation of this type of enterprise involves activities which generate environmental risks manly due to disposal of nuclear waste. The storage of nuclear waste must follow strict international standards and faces the resistance of the civil society. Thus, complex technical and politically procedures are required to find a suitable place for this end. The use of geologic bodies that fit the required features for the installation of nuclear repositories is described in literature. This kind of geological units must be deep, structuralized and with low infiltration. These aspects should to be identified through geologic, hydrologic and geophysical studies and structural models as well.

This study aims to report the results of the regional geophysical survey performed to delimit the gneissic host rocks of Ribeira Belt and the characterization of their magnetic characteristics main textural variations. This work also includes the analysis of the structural features of rocks (faults and fractures), in addition to how these structures change within the massif coupled with mineralogy and chemistry signatures.

The magnetic anomaly map displays a series of semi-circular magnetic highs, following the general configuration of the alkaline intrusions. In Brazil, the intrusive bodies with potential to function as repository are the alkaline complexes, once they are isotropic, massive, have well defined geometry, compatible depth and with low or no human occupation. However special attention to the possible occurrence of water percolations in fractures and faults must be given. In this way, detailed studies of alkaline bodies that fit the expected features comprise the following intrusions: Mendanha, Tinguá, Tanguá, Soarinho, Rio Bonito and Morro de São João. This study intends to be a contribution for the knowledge of the properties of alkaline bodies with potential to be used for storage of nuclear waste, in the near future, in Brazil.

Keywords: Nuclear waste. Repository. Radioactive waste management. Alkaline complexes. 


\section{Introduction}

The disposal of radioactive waste is an issue relevant for the nuclear industry in Brazil. At present, there is no knowledge about its final destination, especially the waste from the spent fuel from nuclear plants of Angra dos Reis, classified as having high radioactivity. In terms of nuclear waste of high radioactivity, the literature emphasizes that geological repositories are ideal places to house these types of materials. Documents divulgated by the International Atomic Energy Agency (IAEA), are listed below among which:

- Site Selection Factors for Repositories of Solid HighLevel and Alpha Bearing Wastes in Geological Formations (IAEA, 1977);

- Underground Disposal of Radioactive Wastes (IAEA, 1981);

- Criteria for Underground Disposal of Solid Radioactive Wastes (IAEA, 1983a);

- Concepts and Examples of Safety Analyses for Radioactive Waste Repositories in Continental Geological Formations (IAEA, 1983b; IAEA, 1994a)

- Regulatory Objectives, Requirements and Guidelines for the Disposal of Radioactive Wastes, Long-Term Aspects (IAEA, 2009)

- Guidance for Regulation of Underground Repositories for Disposal of Radioactive Wastes (IAEA, 1989);

- Siting of Geological Disposal Facilities (IAEA, 1994b);

- Geological disposal of radioactive waste (IAEA, 2011);

- Geological disposal of radioactive waste: technological implications for retrievability (IAEA, 2009).

Based on such perspectives, Enokihara (1983) evaluated that geological formations more favorable for the deposition of nuclear waste are classified in four basic groups: evaporites, other sedimentary rocks, stones and igneous rocks.

As regards the lithologies, especially in relation to the long-term safety associated with nuclear waste, Martins (2009) underlined that the insertion crystalline areas, mainly composed by metamorphic rocks and magmatic rocks (among which alkaline, granite and basic rocks), are the most propitious repositories of nuclear waste. However, these rocks vary enormously in strength, stability, homogeneity, chemical composition, among other factors. This is why not all rocks classified in this way are adequate for the construction of a repository. The greatest problems regarding its use for such end is the presence of failures and/or fractures that weaken some rocky areas and may constitute paths of migration of radionuclides.
The site description is basically needed aiming to: (1) develop and present the geoscientific and ecological understanding of the site; (2) underpin a safety assessment describing different scenarios and consequences if radionuclides are released from the repository; (3) establish a baseline for detecting short- and long-term effects of the repository; (4) provide the basis for the environmental impact assessment describing and evaluating the effects of the construction and operation of a repository; (5) provide input to the development of preliminary designs of the surface and subsurface constructions.

\subsection{Objectives}

In this context, the present work aims to identify and characterize the alkaline complexes as potential areas for future radioactive nuclear waste repositories, which include alkaline complexes located in the southeastern region of Brazil. In the Rio de Janeiro State and its adjacent areas, there are a dozen of felsic alkaline intrusive rock bodies forming WNW-ESE alignments (Amaral et al., 1967; Almeida, 1976), called Poços de Caldas - Cabo Frio alkaline rock alignment (Figure 1), such as Itatiaia, Morro Redondo, Tinguá, Mendanha, Itaúna, Tanguá, Rio Bonito, Soarinho, Morro dos Gatos, Morro de São João, Cabo Frio Island (Motoki, 1979; Brotzu et al., 1989, 2007; Mota et al., 2009; Motoki et al., 2012; Geraldes et al., 2013).

Initially, we discuss about the issue of radioactive waste, presenting their main characteristics. Subsequently, we emphasize the importance of alkaline rocks as repository, especially those with high radioactivity. This contribution has as objective to subsidize the final decision on the location and construction of repositories for the final deposition of radioactive waste in the aspects of site selection, characterization of local, development of technologies for optimizing the performance of the host rocks deposition in the system, the security analysis in function of the underground aquifer, and support to nuclear and environmental licensing.

The operation of the nuclear power plants in Brazil and the use of radioisotopes generate considerable quantities that require the deployment of plants licensed for the deposition, making urgent the definition of a concept of repository for the country, for their subsequent construction and operation. In this sense, the urgent requirement is the beginning of studies for the site selection, design, construction, and licensing for the entry into operation in the shortest time. 


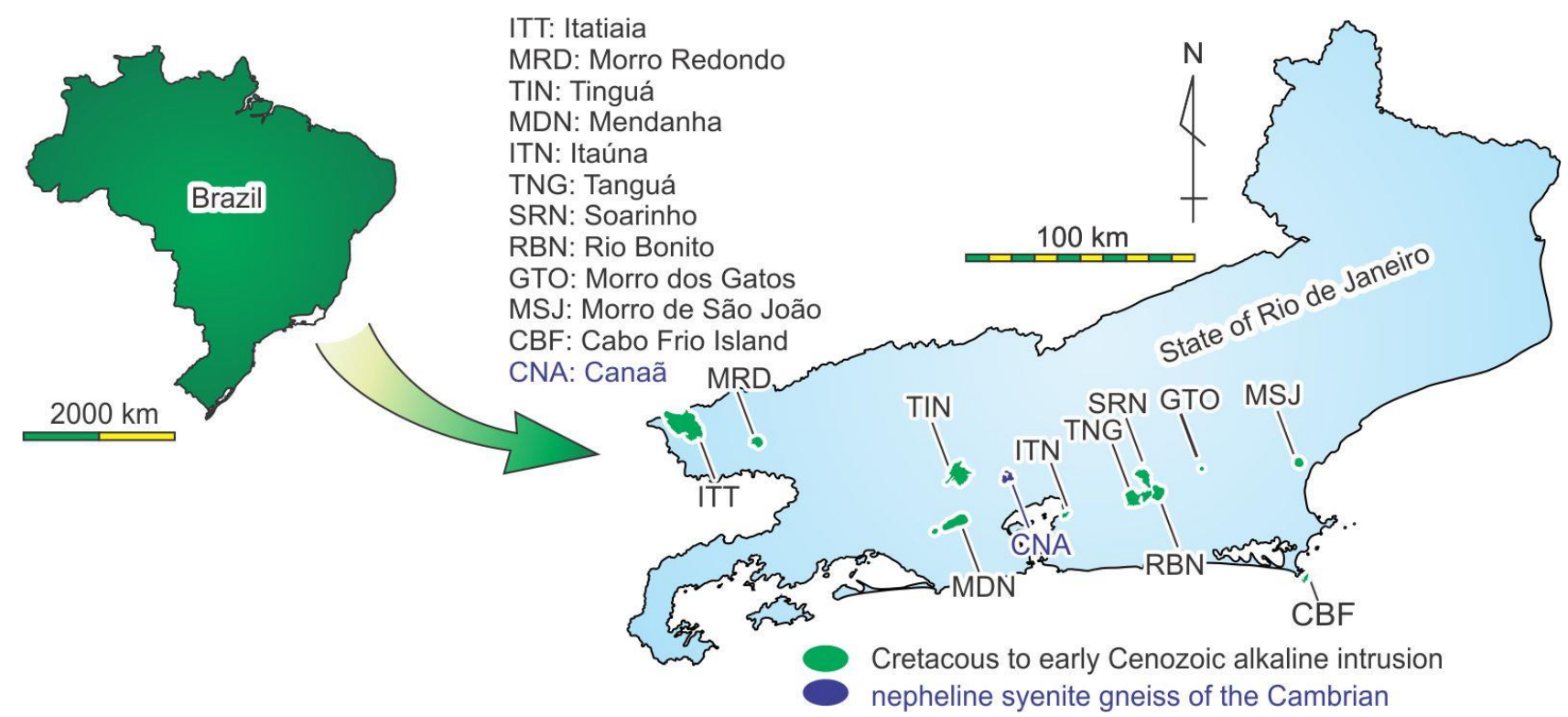

Fig. 1. Felsic alkaline intrusions of the Poços de Caldas - Cabo Frio magmatic alignment of the State of Rio de Janeiro (modified from Motoki et al., 2010; 2011).

\subsection{Radioactive $W$ aste issues}

In agreement with the IAEA (2009), the radioactive wastes are classified into six categories as a function of its activity, as shown in Table 1. The radioactive waste produced in the Angra dos Reis Nuclear Power Plant may be classified in three levels of radioactivity: high, medium and low (IAEA, 2009). For the group of low and average radioactivity (which should stay in the middle tank by a maximum of three years) the destination are two concrete sheds constructed within rocks, beside the plant, where it is stored in drums containing boots, overalls, contaminated clothing used by workers or the metal parts of the reactor and chemical waste.

The group of high radioactivity are formed by already irradiated fuel element inside the reactor, whose half-life is quite long, and may reach tens of thousands of years, making the question on the fate of these wastes of high relevance. Currently, the place of storage of these wastes are done in pools inside the reactor area that keeps the waste submerged at more than 10 meters deep (Freire and Tello, 2007; 2008). However, this type of reject, with the decommissioning of the nuclear power plants, must have as final destination a geological repository.

\subsection{Geological Repositories of Radioactive Rejects}

As underlined by Silva et al. (2015), according to the IAEA the repositories for radioactive waste can be classified in two categories: (A) next to the surface repositories and; (b) geological repositories. The repositories close to the surface are recommended for the radioactive waste of low and middle risk, being then the establishment of an institutional control period is quite important, in view of the risk of intrusion in the long term. The geological repositories (Neves et al., 2007; Silva and Tello, 2007), applicable to highlevel radioactive waste, unlike deposits coming to the surface, are located at great depths, aiming to eliminate the risk of intrusion of humans and animals.

Raduan (1994) evaluated the geological formations as the most adequate to the insulation of dam high level or tailings containing radionuclides with long half-life, radionuclides Transuranium Elements, among others. According to the IAEA (2009), some tailings need a deep geological disposal to avoid problems for the environment and for society. Among such waste, we can highlight those that participate of the nuclear fuel cycle, including own fuel used in the process of generating energy. In addition, the security of a geological deposit is based on the concepts of defense in depth and in isolation, which is supplied by the combined effects of multiple artificial and natural barriers.

In addition to the properties of the host rock, the specific aspects of the project and the degree of filling and sealing of the openings and connections with the surface are highly relevant. Furthermore, certain characteristics of the project, such as the containment of long-lived waste, are clearly 
beneficial. Whereas the geological aspects and its importance as a deposit of radioactive waste, the IAEA observed that hard rocks (granites, for example) are effectively selfsufficient, being necessary only small engineering and maintenance measures to prevent the bank ruptcy of the walls of the rock in cells of deposition and places of access.

Although there are several concepts on the isolation of radioactive waste in the biosphere, during the time needed for its decay, Enokihara (1983) observed that the only alternative that appear viable, from various points of view, is your storage in deep geological repositories, whose main attraction is the fact that many geological formations remained stable for millions of years. In addition, these formations present the three basic requirements for the safe disposal of radioactive materials: cooling, protection and insulation. So, the surrounding rock acts as a heat sink, providing the cooling. The depth of deposition provides adequate protection against radiation, and the size and integrity of rocky formations enables Isolation, preventing the escape of material to the biosphere.

\section{Study area}

\subsection{Geomorphology of Geological Sites Repositories}

Alkaline intrusions are constituted by stocks of the size varying from less than $1 \mathrm{~km}$ up to $15 \mathrm{~km}$ composed of nepheline syenite and alkaline syenite. Small bodies of phonolite and trachyte also occur. In Morro de São João intrusive complex (Brotzu et al., 1989; Mota et al., 2009) and Cabo Frio Island gross-grained mafic alkaline rocks are found. Lamprophyre dykes show fine granulation. These rocks are relatively common in the Rio de Janeiro State and extracted as highly qualified as ornamental construction material (Petrakis et al., 2009). Some of the intrusive complexes such as Itatiaia, Mendanha (Motoki et al., 2012), Itaúna (Motoki et al., 2013a), Morro dos Gatos and Cabo Frio Island (Geraldes et al., 2013) have subvolcanic pyroclastic conduit and fissures made up of pyroclastic rocks (Mota and Geraldes, 2006; Motoki et al., 2013b). Along the alignment, there is Cambrian nepheline syenite gneiss of different genesis called Canaã complex. The intrusive bodies have circular (e.g. Tanguá, Morro de São João) or elliptic (Mendanha, Rio Bonito, and Cabo Frio Island) distribution. The long axis of the elliptic bodies ranges from ENE-SWS to NE-SW.

The main intrusive bodies have rare homogeneous form (Geraldes et al., 2013). That is, the horizontal section of upper level of the pluton is circular and that of lower level is elliptic. Their tilling is supposed to be sub-horizontal and the bottom is considered to be fissure-like feeder of the felsic alkaline magma.

The nepheline syenite and alkaline syenite is made up mainly of alkaline feldspar, nepheline, alkaline clinopyroxene, amphibole, and biotite with accessory minerals of ilmenite, magnetite, apatite, and titanite. The alkaline feldspar can show interlocking perthite but no flame perthite and string perthite are observed. The perthite type indicates that this feldspar it is not so strongly potassic but intermediate one. Several rock bodies, such as Tanguá has amphibole but no clinopyroxene (Motoki et al., 2012). The Morro dos Gatos syenite has exceptional composition on the border line between syenite and monzonite. This rock contains clinopyroxene and biotite but no amphibole is observed. Zircon is not found in nepheline rich rocks. The amphibole occurs frequently along the border of the clinopyroxene and some amphibole crystals are pseudomorph of clinopyroxene. The rocks without nepheline can have little amount of zircon and quartz. The nepheline syenite of Tanguá and Morro de São João complexes present local occurrence of pseudoleucite.

The alkaline intrusive complexes (nepheline syenite, alkaline syenite, phonolite and trachyte) form morphologic elevation with relative height of 300 to $900 \mathrm{~m}$, called locally alkaline massifs. Their minerals (especially nepheline and alkaline feldspar) are vulnerable to chemical weathering under humid tropical climate. This controversy is explained by the phenomenon called weathering passivity (Motoki, 1979), that is, the highly impermeable regolith composed of clay minerals originated from the chemical weathering protects the massif preventing the surface water percolation into the rock body. Therefore, the alkaline rocks present just below the regolith is fresh and mechanically very firm.

According to the fission track dating for apatite, the present exposure is considered to be subvolcanic structure of $3 \mathrm{~km}$ below the surface of the eruption time (Figure 2). The volcanic edifices and surface eruptive materials of that time have been completely eliminated by the regional uplift of $3 \mathrm{~km}$ that occurred up to $40 \mathrm{Ma}$ (Geraldes et al., 2013).

\subsection{Origin of Cretaceous Alkaline Rocks}

The origin of the felsic alkaline magmas is not clear. In outcrops, highly felsic nepheline syenite and alkaline syenite are found with rare occurrences of mafic alkaline rocks. And intermediate alkaline rocks aren't common. It is difficult to accept the fractionation crystallization model of mafic alkaline magma. In addition, there are small number of rocks at the contact zone of the Mendanha (Motoki et al., 2012) and Cabo Frio Island intrusions, silica saturated. And the existence of pseudoleucite in the nepheline syenite with low 
silica indicates that relatively less-differentiated felsic alkaline magma is K-rich and it becomes Na-Rich by means of fractionation crystallization.

Motoki et al. (2013a), based on the chemical analyses and their petrological interpretation, proposed a magma evolution model in three-stages (Figure 3). The relatively less differentiated nepheline syenite magma has high $\mathrm{K}_{2} \mathrm{O} /\left(\mathrm{Na}_{2} \mathrm{O}+\mathrm{K}_{2} \mathrm{O}\right)$ ratio. This magma crystallized leucite and the residual magma has lower $\mathrm{K}_{2} \mathrm{O} /\left(\mathrm{Na}_{2} \mathrm{O}+\mathrm{K}_{2} \mathrm{O}\right)$ ratio (stage 1) and continues up to the arrival of residual magma composition at the cotectic curve. Leucite crystals transform into pseudoleucite during slow cooling of the magma. Examples of this stage are found in Tanguá and Morro de São João complexes. The next process (stage 2) is alkaline feldspar crystallization, where this feldspar is expected to be moderately potassic one with $\mathrm{KAlSi}_{3} \mathrm{O}_{8}: \mathrm{NaAlSi}_{3} \mathrm{O}_{8}$ proportion ranging from 0.6:0.4 to 0.7:0.3. The residual magma becomes from K-rich to Na-rich sliding on the cotectic curve (by means of the fractionation of the alkaline feldspar). These examples are commonly found and continues up to the lowest temperature point on the cotectic curve. Some samples (Cabo Frio Island, Itaúna, Itatiaia and Rio Bonito) indicate that the magma composition arrived at the point close to the lowest temperature. During this stage, the assimilation of continental crust rocks can take place, with the magma composition was pulled up from the cotectic curve to the granite composition, crossing over the thermal divide. This process is called stage 3 and form felsic alkaline rocks without nepheline and are found at Mendanha, Soarinho, Morro dos Gatos, and Cabo Frio Island.

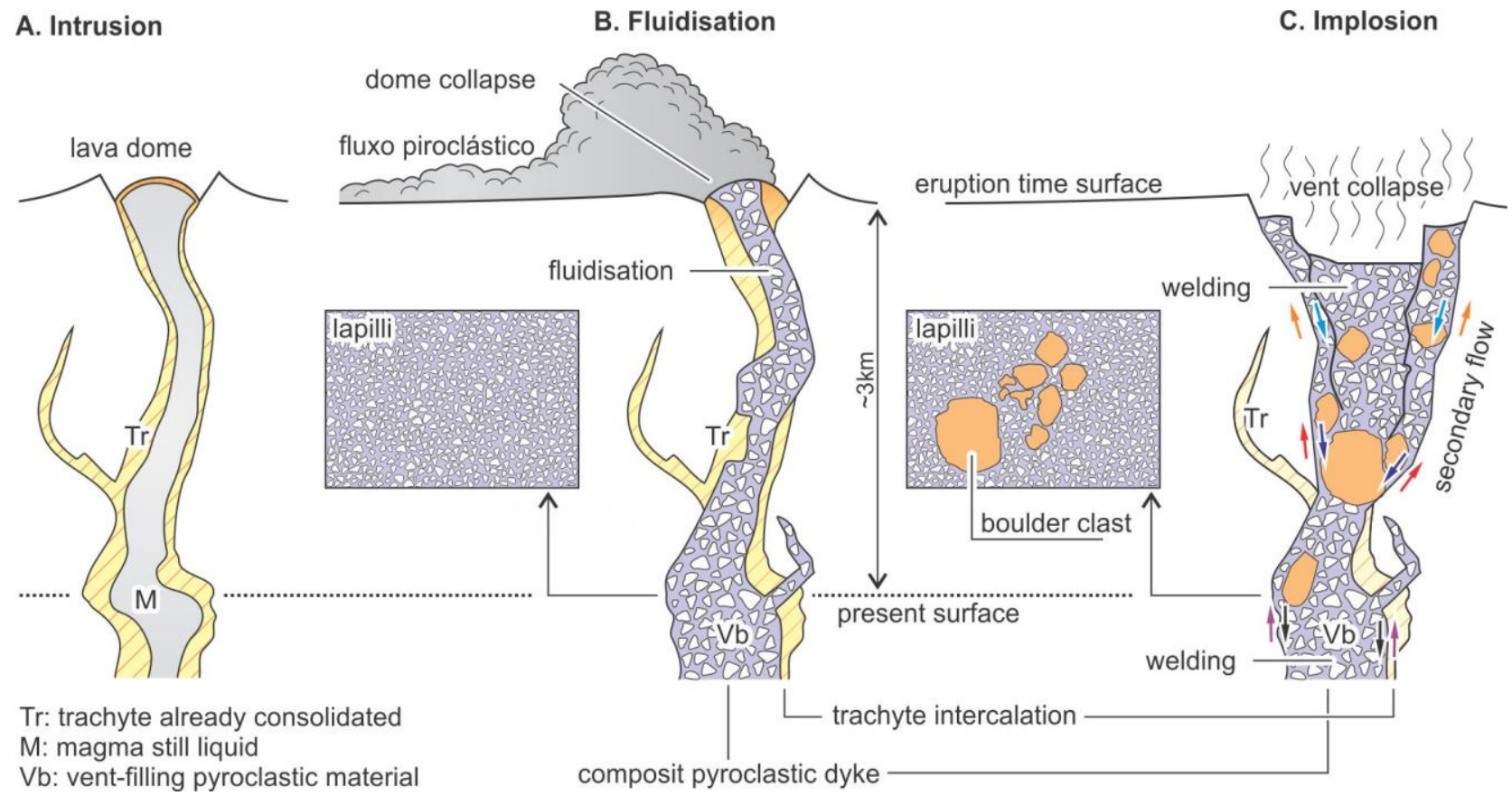

Fig. 2. Schematic illustrations for the formation processes of the pyroclastic rocks of the Mendanha, Itaúna, Morro dos Gatos, and Cabo Frio Island, after Motoki et al. (2012): A) An intrusion of trachyte dyke and lava dome formation on the surface; B) Magma fluidization and pyroclastic flow emission; C) Conduit implosion by vent collapse and welding and secondary flowage of vent-filling pyroclastic materials.

The frequency of radiometric ages from post-breakup rock samples (described in detail below) from the South Atlantic (Figure 3) can be divided into four main classes: Upper Cretaceous (60-80 Ma), with more than 40 radiometric ages for the intervals; Miocene to Recent, with 10 to 20 ages; and the less frequent radiometric ages for the mid to late Tertiary (20-50 Ma) and mid Cretaceous (90-105
Ma). Cabo de Santo Agostinho magmatic province, onshore the Pernambuco-Paraíba coastal basins (Figure 1), registered the oldest magmatic event that post-dates the inception of oceanic crust in NE Brazil.

The magma evolution crossing over the thermal divide does not occur in normal crystallization fractionation because of the thermodynamic instability. However, the 


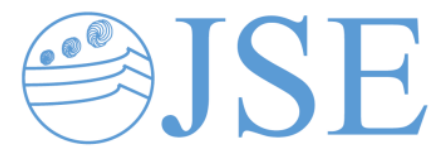

RESEARCH PAPER thermal divide in this composition is not so high, about $50^{\circ} \mathrm{C}$, and therefore, small magma super-reheating and/or lowgrade fluid enrichment can solve it (Motoki et al., 2012). These phenomena can saptake place by new magma injection into the magma chamber, helping country rock melting. The magma super-reheating can form mafic and opaque minerals of desorption shape. The resorted clinopyroxene and magnetite are commonly found in the nepheline syenite and alkaline syenite of this area. The fluid enrichment could transform the clinopyroxene into amphibole. Such examples are observed in the nepheline syenite of Mendanha and Tanguá.

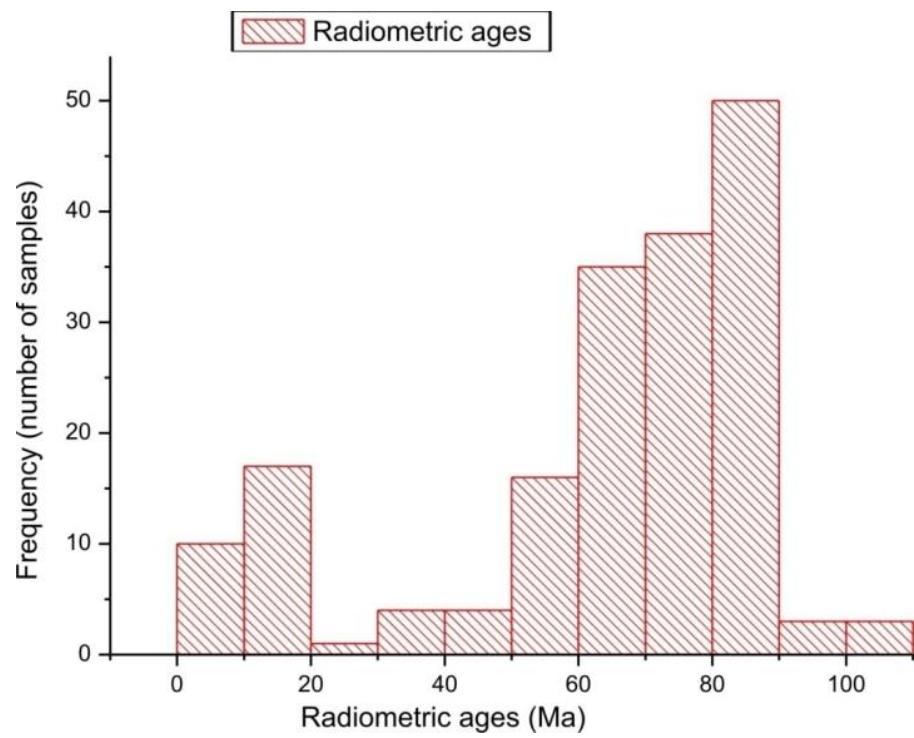

Fig. 3. Histogram of radiometric ages (from Motoki et al., 2013a).

The pyroclastic rocks present at Mendanha and Itaúna were considered as constituent rocks of surface volcanic deposits. Based on this idea, they were interpreted to be extinct volcanic edifices. However, recent researches (Motoki et al., 2013 a; b) revealed that these rocks are not components of pyroclastic flow or pyroclastic fall deposits, but of vent-filling welded tuff breccias, that is, subvolcanic conduits and fissures.

The contact planes between the pyroclastic bodies and their host rock are subvertical without intercalation of palaeosoil and organic materials. Therefore, the outcrops are considered to be intrusive contacts. Intrusive pyroclastic rocks are little known in the world (e.g. Ekren and Byer, 1976; Motoki, 1979; Reedman et al., 1987; Kano et al., 1996; Wolff et al., 1999). Some of the pyroclastic bodies has been described as pyroclastic dyke and are very small, less than 4 $m$ wide (Motoki et al., 2012). A pyroclastic dyke of the Morro dos Gatos is made up of densely welded intrusive tuff.

\subsection{Petrography and Magnetometry of Alkaline Intrusions}

Geologic studies conducted by university and government agencies showed that the continental alkaline magmatism in SE Brazil (Figure 4) occurs as plugs, stocks, dykes and sills that present several trends, evidenced by geological and geophysical datasets: a general ENE direction for the dykes, and to NW/SE and E-W lineaments. These alkaline complexes most probably represent the roots of extinct Cretaceous volcanoes (Figure2). Over time the volcanic superstructures have eroded and just the plutons remained, as is also observed in present day in Cameroon Line volcanoes (Gulf of Guinea) that have been deeply eroded.

In Southeast Brazil, between longitudes $42^{\circ}$ and $47^{\circ} \mathrm{W}$, a linear alignment of alkaline igneous intrusive complexes occurs with ages ranging from 85 to $55 \mathrm{Ma}$ (Figure 3). Over a length of $500 \mathrm{~km}$, they were emplaced into the northern segment of the Neoproterozoic Ribeira belt. With $800 \mathrm{~km}^{2}$, Poços de Caldas is the largest alkaline complex in Brazil and one of the largest in the world. The alkaline intrusions present some residual relief bodies, in part formed by plutons of alkaline nature, lined up according to WSW-ENE trend (Figure 1). As an example, the smaller Itatiaia/Passa Quatro complexes, with peaks up to $2.800 \mathrm{~m}$ above sea level, represent the highest elevations on the Atlantic side of South America (Ulbrich and Gomes, 1981).

In addition, the Cananeia and Jacupiranga intrusions, located between Paraná and São Paulo states, are well known for their complex lithologies and some economic importance, as P-rich minerals are explored in carbonatites from Jacupiranga. In São Paulo, there are several alkaline complexes, the most important are the Ponte Nova, Passa Quatro intrusives and the São Sebastião Island, which is associated with three alkaline intrusions.

In Rio de Janeiro State the most important intrusions (Figure 4) are located between Serra do Mar (Ocean Range) and the coastline adjacent to the Santos and Campos basins (Almeida et al., 1976). Such alignment includes Mendanha Massif, Itatiaia, Morro Redondo, Piraí (or Tomazes ridge), Tinguá, Itaúna, Monjolos, Porto das Caixas, Tanguá, Soarinho, Rio Bonito, Morro dos Gatos, Guia de Pacobaiba, Cabo Frio Island and São João plutons. 


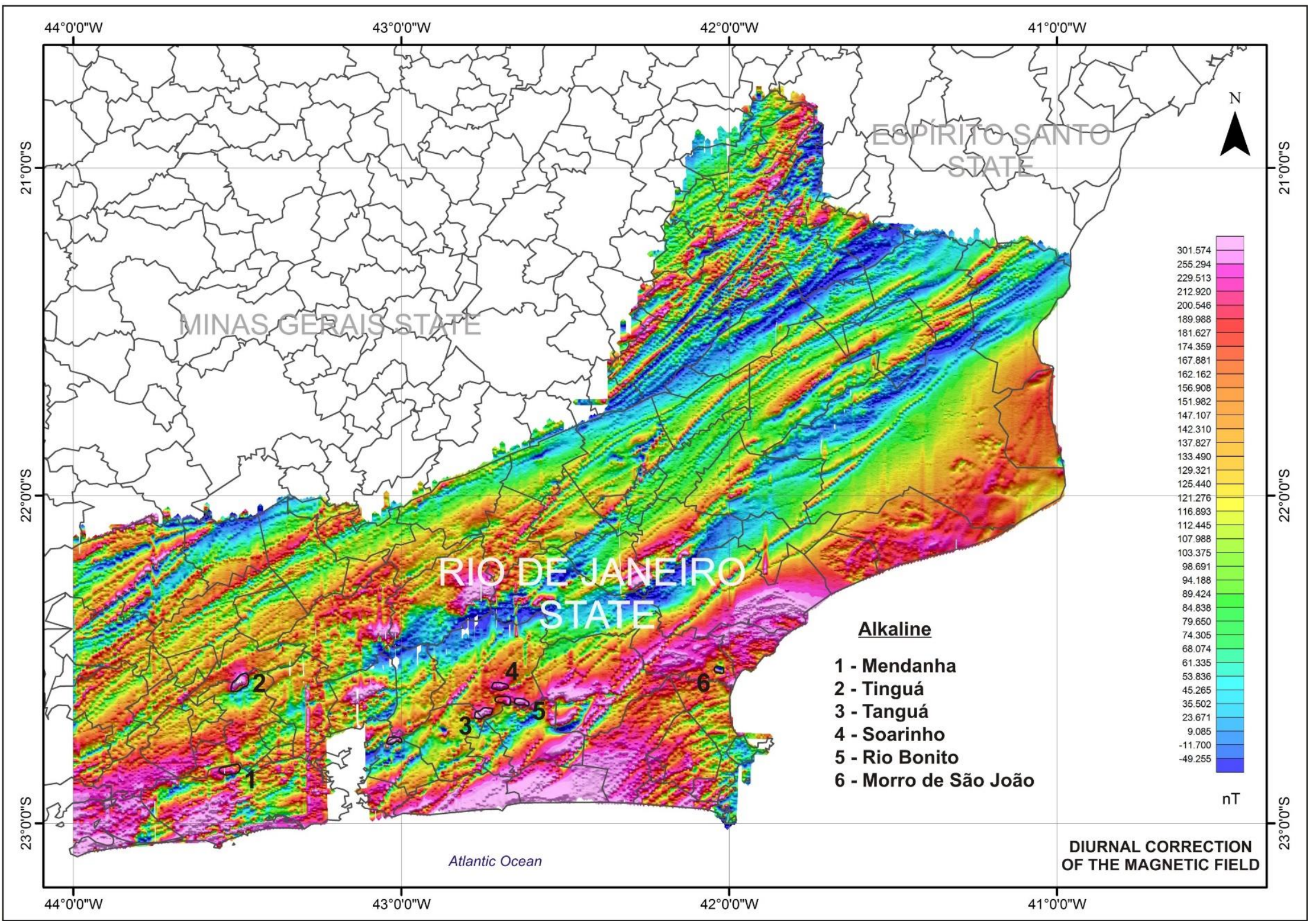

Fig. 4. Magnetics survey by São Paulo-Rio de Janeiro project (data available from CPRM, Brazilian Geological Survey). 


\section{Material and methods}

This work presents geologic details of the intrusions and aeromagnetic regional features of some of the most important intrusions of Rio de Janeiro State, such as Mendanha Massif, Tinguá, Tanguá, Soarinho, Rio Bonito, Morro de São João (Figure 4) and Itatiaia.

The mapping allowed to delineate the contact between the alkaline intrusions and the basement rocks. The local basement is composed of Paleoproterozoic orthognaisses where biotite-gneiss and biotite-hornblende-gneiss appear. In addition, structure features were delineated from satellite images

The mapping on the scale of detail $(1: 10,000)$ within the alkaline bodies allowed the identification of felsic and mafic lithotypes, the complexity of the contacts as well as the distribution of the lithotypes. In this sense, the fieldwork followed by the petrographic studies allowed characterizing the alkaline rocks in the studied intrusions.

The aeromagnetic survey data used in this study covers the area of Rio de Janeiro State and was acquired by Companhia de Pesquisa de Recursos Minerais (CPRM; Geological Survey of Brazil) in 1978 and corresponds to a $150 \mathrm{~m}$ height aero survey, with $1 \mathrm{~km}$ of line spacing and 10 $\mathrm{km}$ control line spacing.

In order to study the crustal structures in detail, an aeromagnetic anomaly map with high resolution was produced. In this way, the magnetic anomalies map allowed a better comparison with the local tectonics and major geological features. The magnetic data was surveyed with a Geometrics G-803 proton precession magnetometer with the sensor placed on the tail of the aircraft. The airborne dataset was initially processed by CPRM (2000) and its results are leveled grids $(250 \mathrm{~m}$ cell size $)$ of several geophysical themes, such as Total Magnetic Intensity Anomaly, Magnetic Field Diurnal Correction and Analytic Signal.

\section{Results}

\subsection{Mendanba}

The Mendanha Massifs a young alkaline complex (80-53 Ma, K/Ar; $64 \mathrm{Ma}$ Ar/Ar, according to Geraldes et al., 2013; Mota et al., 2014) inserted in a NW-SE magmatic alignment in Rio de Janeiro State (Figure 5). It is distinguished by including sub-volcanic and volcanic types, identified in other plutonic provinces in this alignment.

The Mendanha Massif comprises a non-saturated suite predominantly composed by foyaítes, tinguaytes and nefeline syenites, with mineralogical and textural variation showing syenitic, trachitic lavas and breccias intercalation (Figure 6). The plutonic suite and trachitic lavas are associated with two main volcanic structures. The first one is a $2 \mathrm{~km}$ large conduct named Nova Iguaçu volcano structure which consists of central agglomerate with bombs and abundant tuff and lapilli. The second one, the Lamego Chamber, is a smaller conduct of trachitic welded tuffs and volcanic breccias. Minor occurrences of barite and bauxite had been described in the Mendanha Massif (Mota and Geraldes, 2006; Mota et al., 2012). The record of the volcanic structures can suggest fast explosive magmatic processes possibly controlled by ascendant hot gases, with suspended fragments (fluidization) accumulated in flat magmatic chambers.

\subsection{Tinguá}

The Tinguá alkaline complex $\left(120 \mathrm{~km}^{2}\right)$ is located at north of Rio de Janeiro city. These rocks intrude into the Precambrian basement (Figure 7), which is represented by the Juiz de Fora metamorphic complex (no available ages for this intrusion).

\subsection{Itatiaia}

The Itatiaia massif is structurally linked to the SE Brazilian continental rift, which developed following an ENE to EW trending transcurrent system inherited from the Brasiliano (Pan African) Cycle and which was also reactivated during the breakup of Gondwana. This alkaline complex (Figure 8) is composed of syenites, pulaskites, foyaites, quartz syenites and magmatic breccias (Figure 9). The mean $\mathrm{K}-\mathrm{Ar}$ age obtained on ten biotite samples from the Itatiaia rocks is $70.5 \pm 3.3 \mathrm{Ma}$ (Geraldes et al., 2013).

\subsection{Tanguá}

The Tanguá Hill is the western most intrusion associated with the Rio Bonito Massif, which is located between Rio de Janeiro and Cabo Frio (Figure 10). The alkaline massif yields radiometric ages of about $72 \mathrm{Ma}$ (Geraldes et al., 2013) and includes several rock types, such as nepheline syenite, alkaline syenite, breccias and phonolites (Figure 11). The Tanguá alkaline intrusive body is composed predominantly of coarse-grained nepheline syenite of light grey macroscopic color, with alkaline feldspar, clinopyroxene, nepheline, amphibole and biotite. Magnetite, titanite, and apatite are accessory minerals. Zircon is scarce. The clinopyroxene (light green in parallel nicol) indicate aegirine-augite composition. They are frequently surrounded by amphibole, suggesting the reaction between the clinopyroxene and hydrated magma, commonly observed in the alkaline syenite and nepheline syenite of other intrusive complexes. 


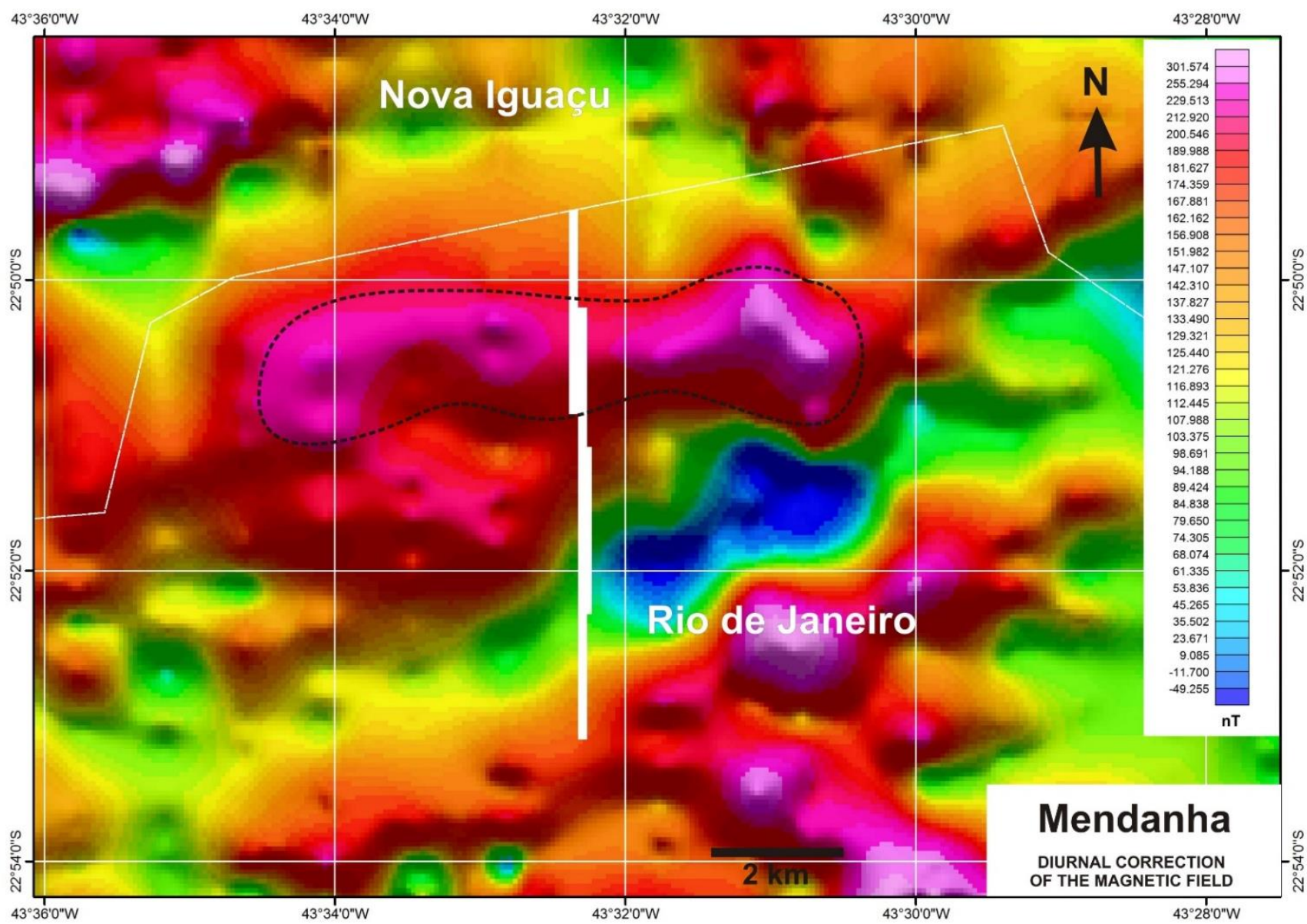

Fig. 5. Regional aeromagnetic features of Mendanha alkaline intrusion.

\subsection{Soarinho}

The Soarinho alkaline complex $\left(148 \mathrm{~km}^{2}\right)$ is close to Guanabara Bay and was emplaced into the Precambrian metamorphic complexes of Juiz de Fora, Paraiba do Sul and the Açungui Group (Figure 12). Alkali plutonic rocks (nepheline syenites) with minor phonolitic dykes are the main lithological types. The $\mathrm{K}$-Ar age is $67 \pm 3 \mathrm{Ma}$ (Geraldes et al., 2013), obtained on only one sample of amphibole separated from a nepheline syenite.

Alkaline syenite is similar to the nepheline syenite but without modal nepheline. Outcrops of this rock show light grey color in macroscopic and difficult to be distinguished from the nepheline syenite by naked eye observations (Figure 13). Its distribution is limited only along the contact zone. Alkaline feldspar, clinopyroxene and amphibole, with magnetite and apatite as accessory minerals composed the rock. The abundance of host rock xenoliths is remarkable and they show notable plastic deformation by the host magma heat.

\subsection{Rio Bonito}

The Rio Bonito Massif, with approximate direction WNW, is part of the alignment of alkaline rocks of the macro region. It is seated on gneisses pre-Precambrian shields of the Ribeira Belt (Figure 14) and is composed of light gray rocks with dark coarse to medium granular texture. The mineralogical composition of these rocks is composed of $\mathrm{K}$ feldspar, orthoclase feldspatoids, amphibolies micropertitic, highlighting the nepheline, plagioclase, titanite, biotite, apatite and opaque minerals.

The studied rocks were classified as nepheline, foiaite and micro-foiaite, in their majority, besides normative pulaskite, and volcanic breach. The Massif is cut by phonolite dikes, trachite, phonolite porphyry and lamprophyre (Figure 15). Regarding the silica, they are intermediate. The classification by diagrams confirms that the nepheline cyanide field is most representative. 

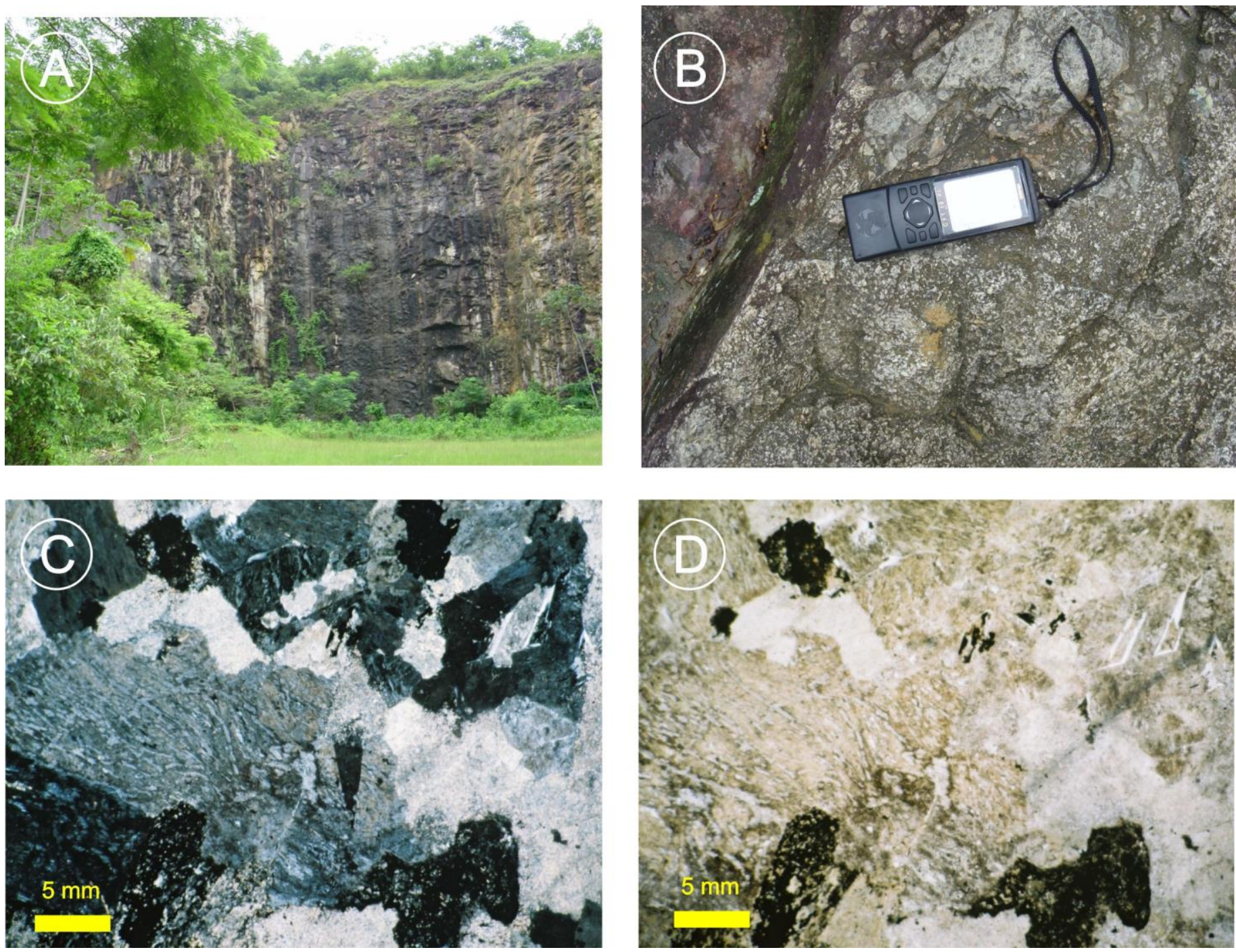

Fig. 6. The Mendanha rocks (A) are grained felsic syenite (B, C and D) and trachyte.

Geochemical investigations of Motoki et al. (2013b) have determined the generation of rocks in environment intraplate. Diagrams Harker of studied rocks indicate alkaline magmatic processes of differentiation. The patterns of REE (Rare Earth Elements) corroborate with this hypothesis which indicate positive anomalies of Eu (Europium) for more differentiated rocks and negative ones for more primitive samples.

The studied rocks are of an orogenic cratonic environment. Have origin in the mantle and the processes of formation can be correlated to the action of a mantle plume or through crustal flexure, where sediment deposited on the nearby continental shelf to the west have led to the opening of faults that have reached the lithosphere. This magmatic event presents the Ar cooling age of $65.03 \pm 0.70 \mathrm{Ma}$ (Geraldes et al., 2013).

\subsection{Morro de São João}

The Morro de São João Alkaline Complex is located in the NE part of Rio de Janeiro State, near the border fault of the Campos Basin, and shows a pronounced topography near the coastline (Figure 16).

Magnetometric survey of these rocks indicates a magnetic pole inversion recorded during the crystallization of the alkaline magma. 


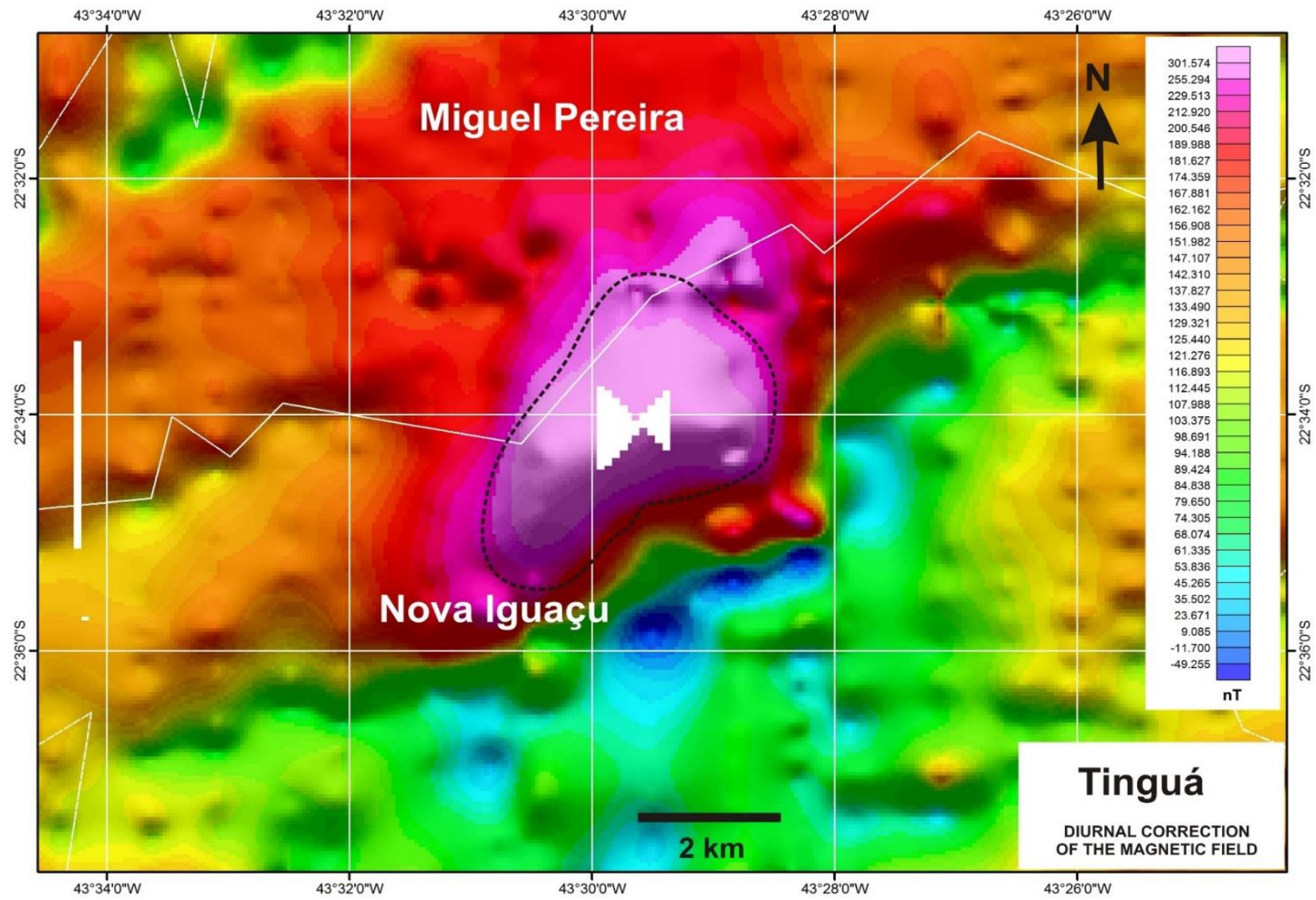

Fig. 7. Regional aeromagnetic features of Tinguá alkaline intrusion.

The intrusive Morro de São João is characterized by the following lithologies: coarse-grained felsic syenite (Kfeldspar, nepheline, hornblende, titanite and pseudoleucite), and mafic syenite (with K-feldspar, hornblende and pyroxene). Petrography (Figure 17) and litho-geochemistry data (Mota et al., 2014) suggest a bimodal suite. Felsic and mafic magma mixing and mingling textures are locally observed indicating the presence of coeval magmas, as indicated by Ar cooling age of $84 \mathrm{Ma}$ (Geraldes et al., 2013).

\section{Discussion and Conclusion}

The Brazil initiated its nuclear program in the decade of 70 , through the installation of the Mine Osamu Utsumi in Alkaline Complex of Poços de Caldas (Minas Gerais, Brazil) and installation of the Thermonuclear Plant Angra 1, in the city of Angra dos Reis (Rio de Janeiro, Brazil).

The deployment of this type of project involves some activities and potential hazards that can be summarized into: mining with production of acid drainage and particles of uranium; production of yellow cake and eventual contamination resulting from the process; activity of the mill itself, with generation of radionuclides radioactive, possible leaks, the tailings profile produced and materials used in the maintenance of the Thermonuclear Plant. In this sense, along with energy produced by this type of plant, radon and xenon gases (elements of difficult containment) and isotopes are produced exclusively by reaction within the reactors and such products as that do not occur naturally in the environment (Efremenkov, 1989).

These isotopes present high radioactivity with emission of alpha $(\alpha)$ particles, beta $(\beta)$ particles and gamma $(\gamma)$ ray energy and have a longer half-life ranging between days and millions of years, and so the disposal of this material must meet strict international standards (IAEA, 1995, 2000, 2002, $2003,2011)$. The production of that high level radioactive reject increased with the installation of the Thermonuclear Plant Angra 2, located within the same complex of Angra1. 


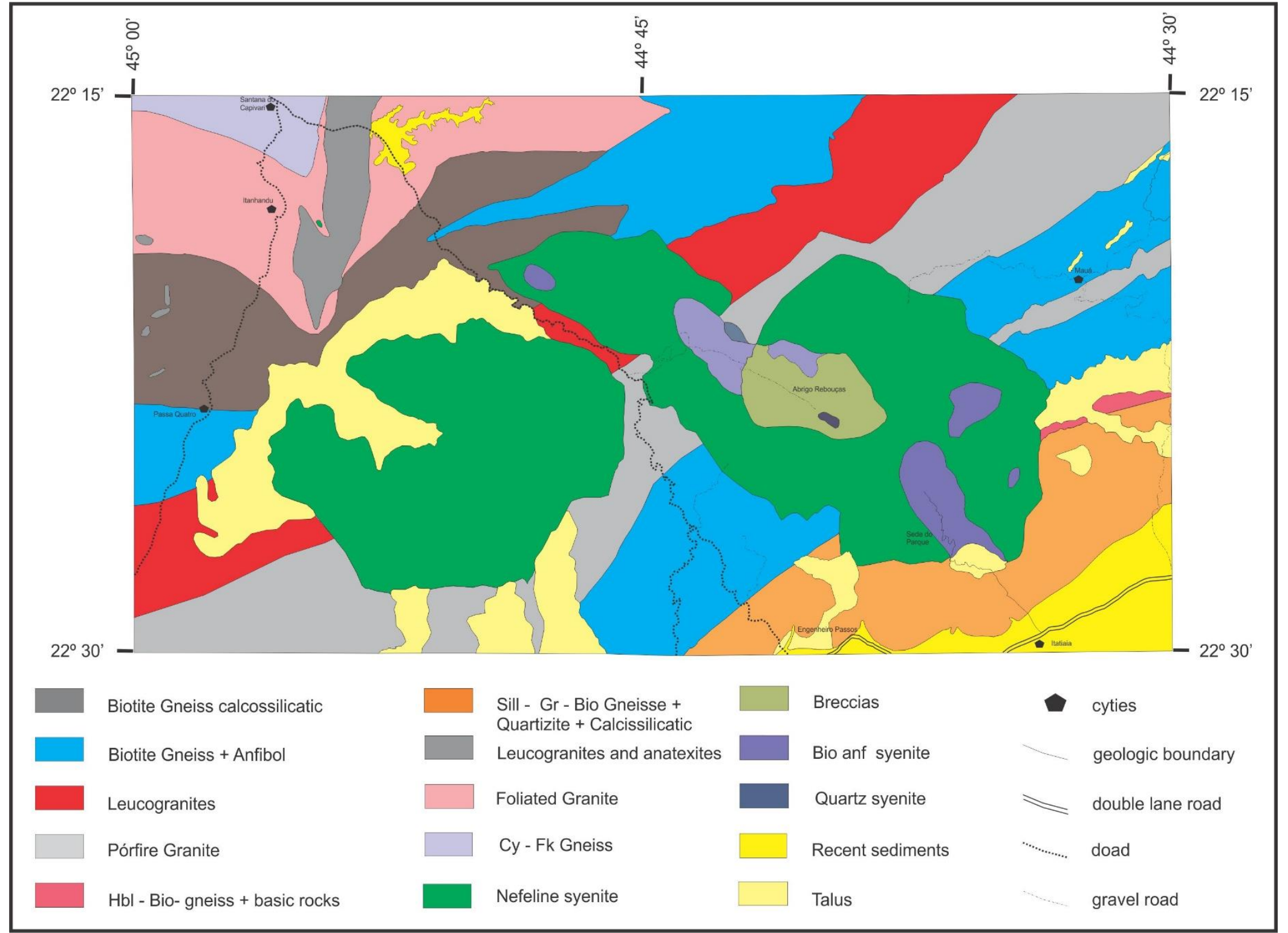

Fig. 8. Geologic map of Itatiaia region. 


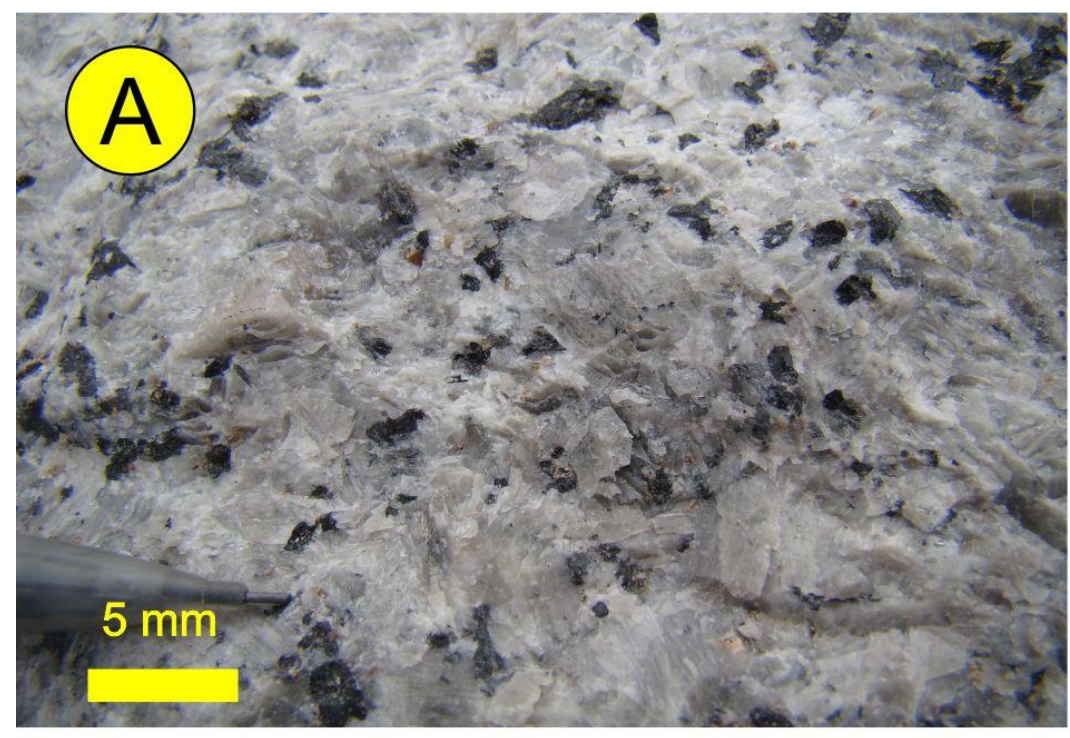

RESEARCH PAPER
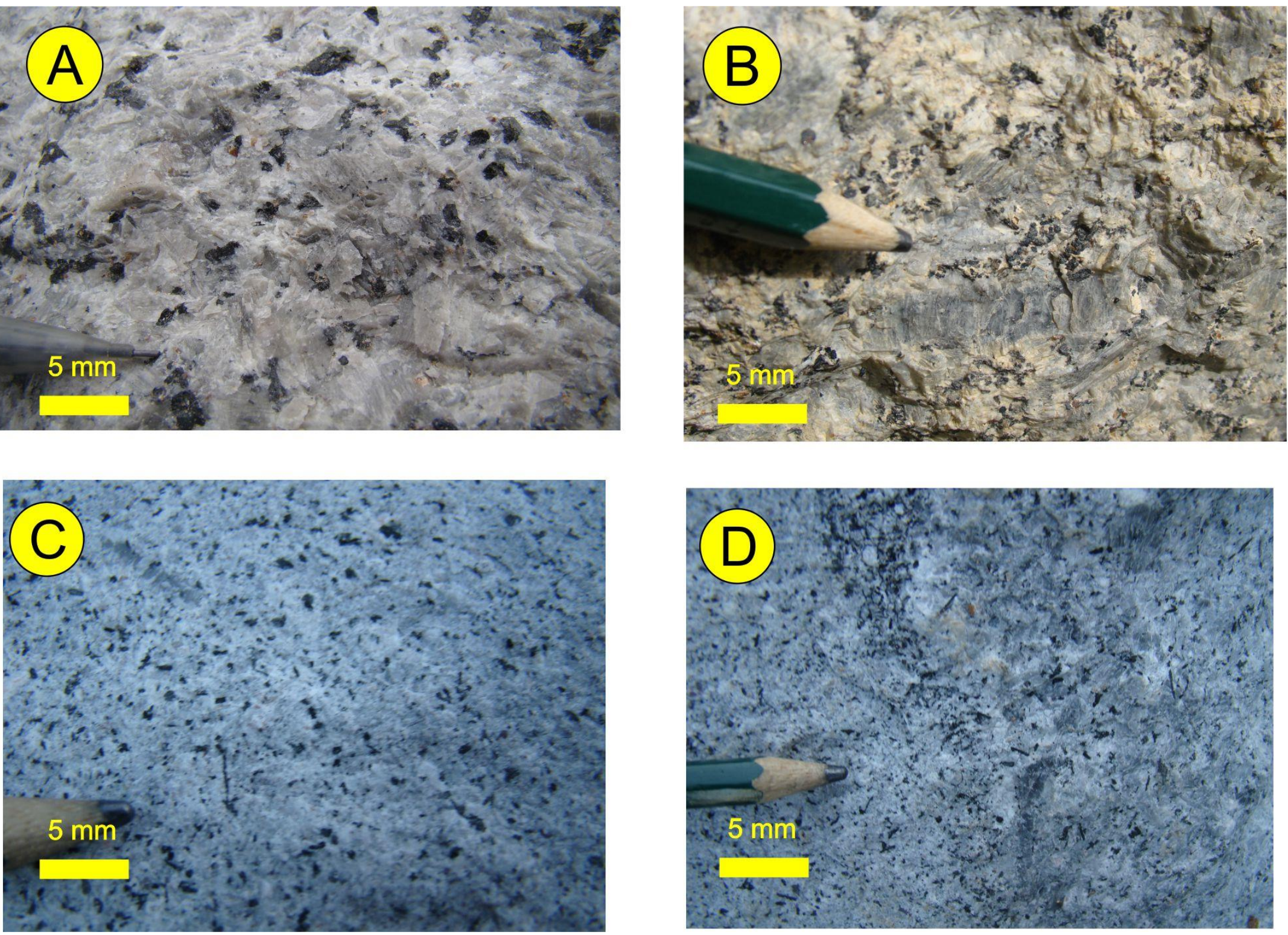

Fig. 9. The Itatiaia alkaline complex is composed of syenite (A), quartz syenite $(C)$ and magmatic breccias $(B$ and $D)$. 


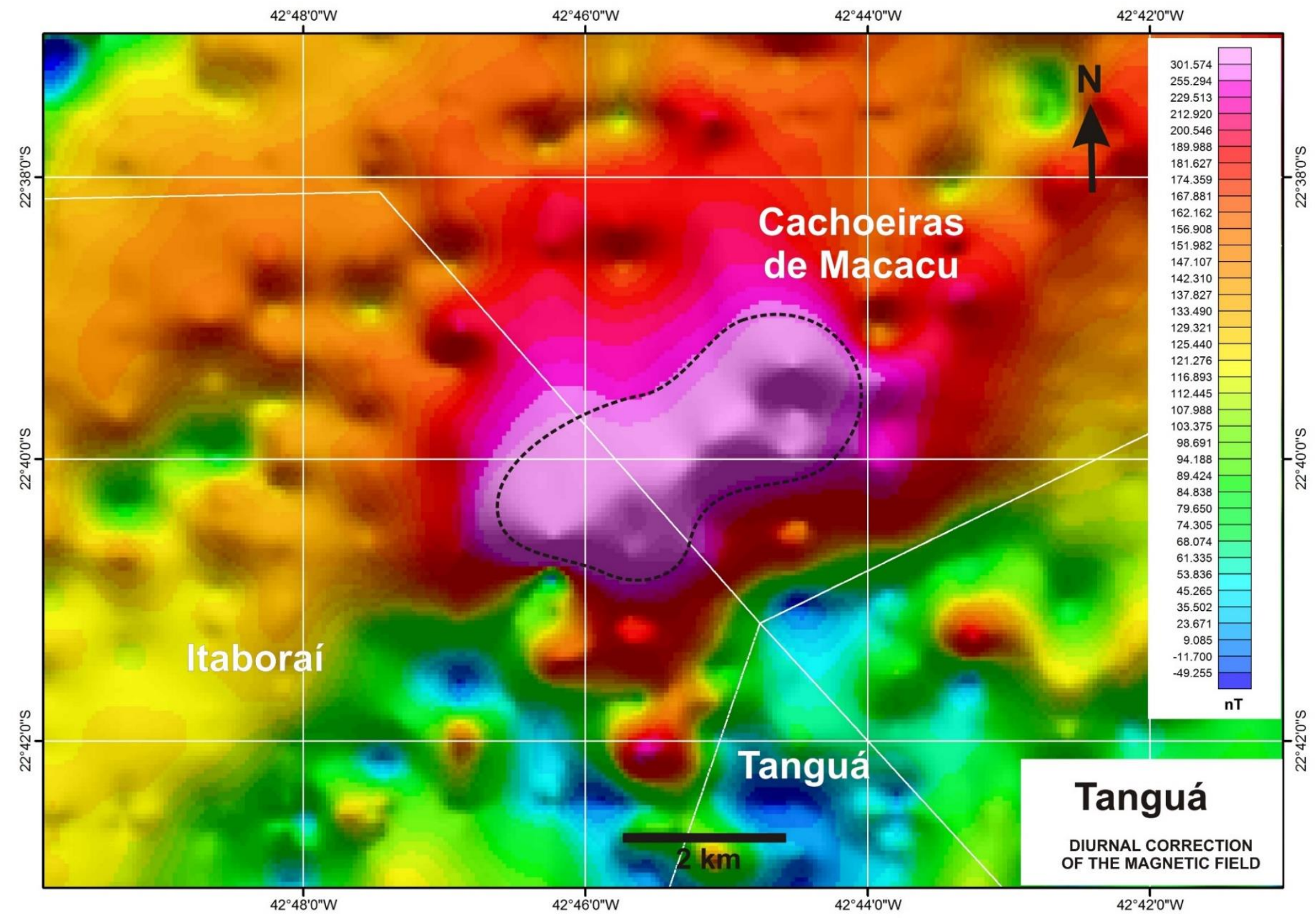

Fig. 10. Regional aeromagnetic features of Tanguá alkaline intrusion. 

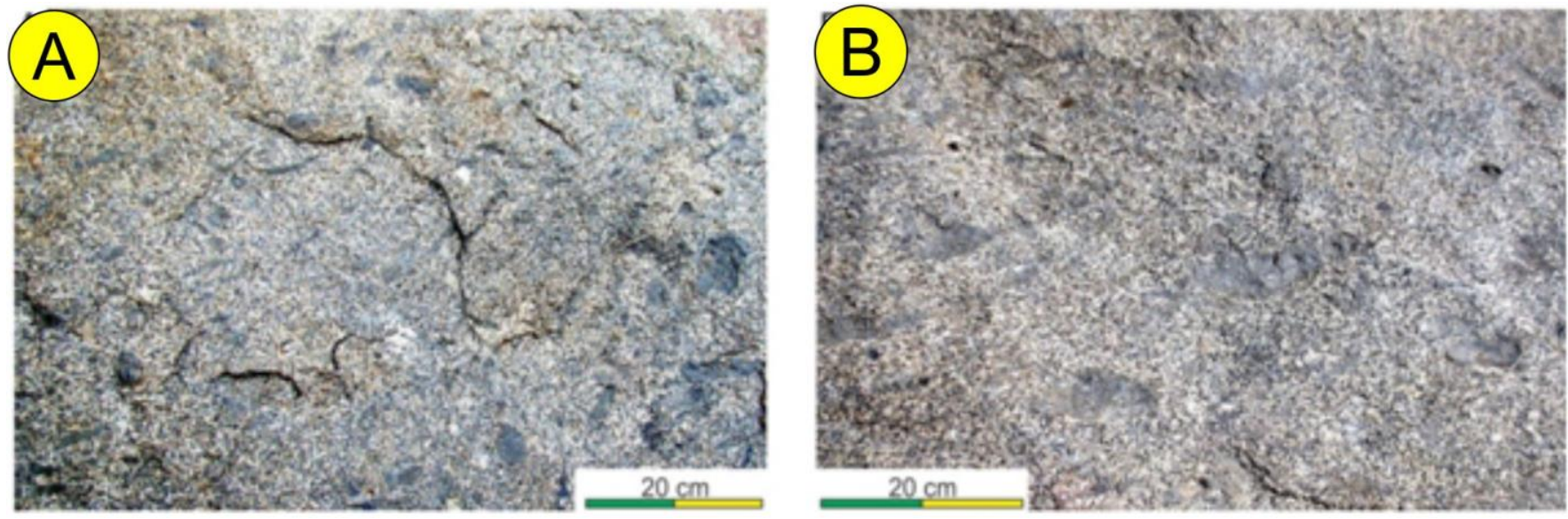

Fig. 11. Plastically deformed (A) and digested (B) host gneiss xenoliths in the alkaline syenite at the south-western contact zone of the Tanguá intrusive complex.

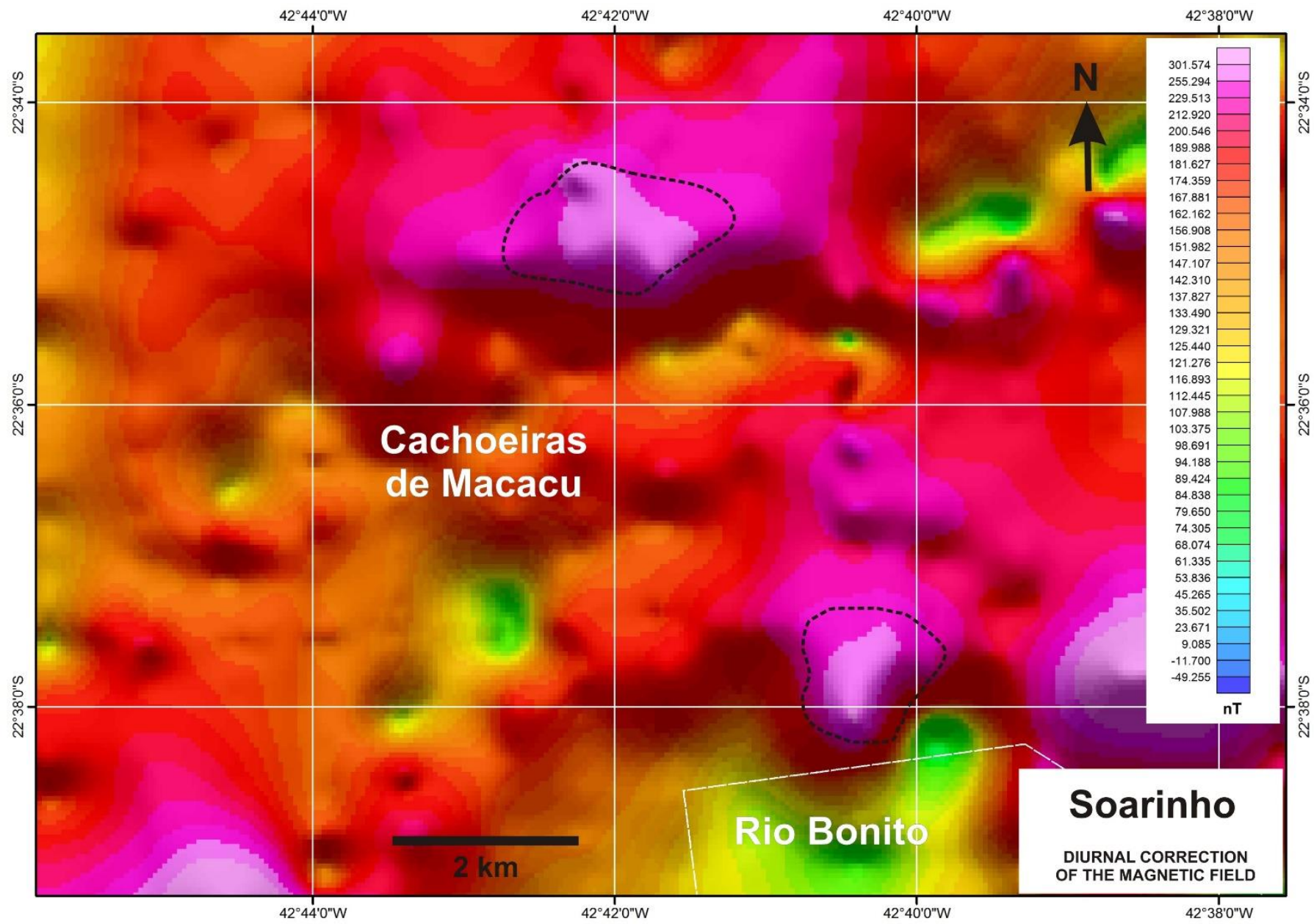

Fig. 12. Regional aeromagnetic features of Soarinho alkaline intrusion. 

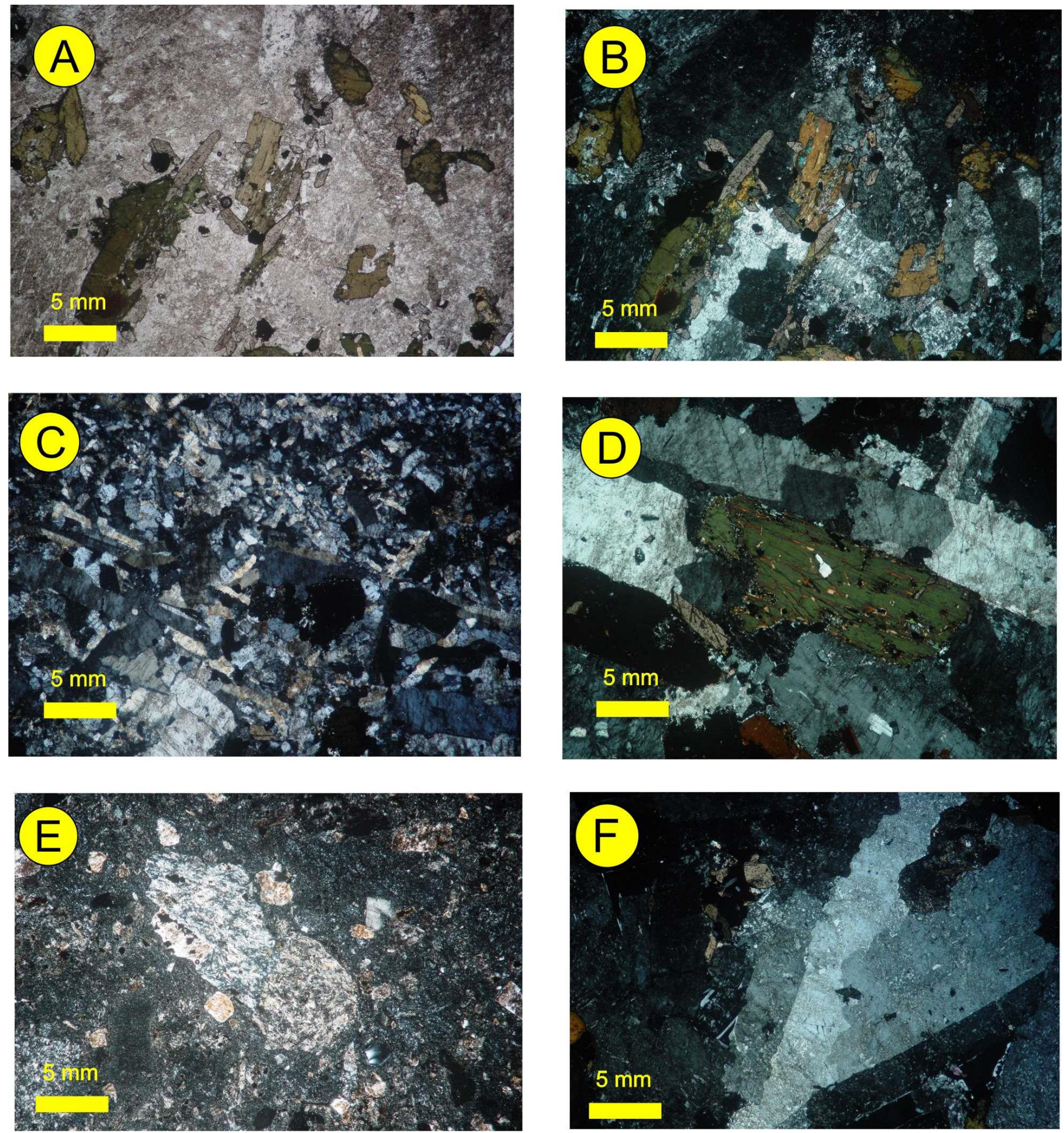

Fig. 13. The Soarinho rocks are classified as nepheline syenite (A and B), micro-foiaite (C), foiaite (D) and volcanic breaccias (E). The massif is cut by phonolite dikes, trachite, phonolite porphyry $(\mathrm{F})$ and lamprophyre. 


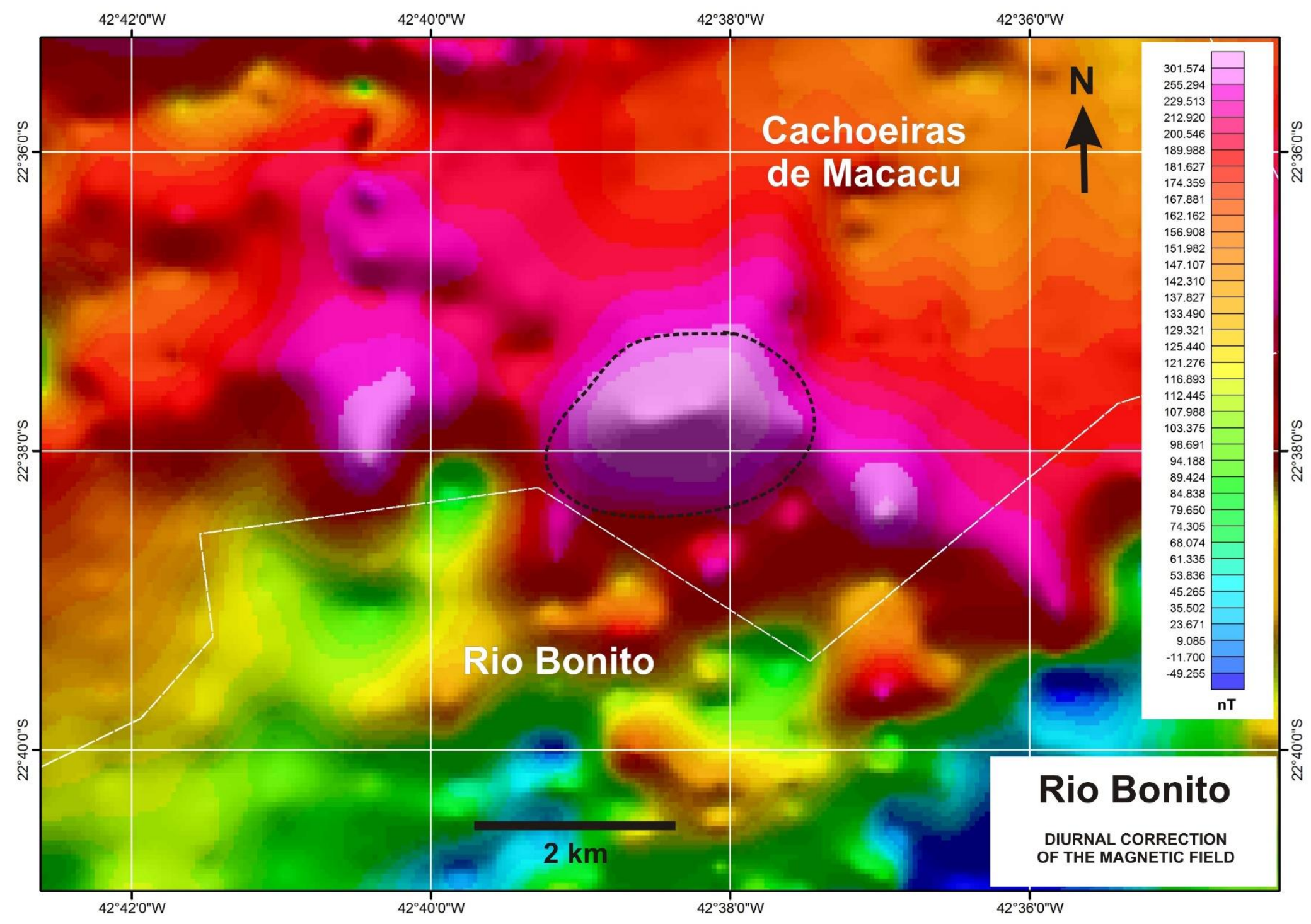

Fig. 14. Regional aeromagnetic features of Rio Bonito alkaline intrusion. 
Currently the waste produced has been stored inside of own reactors of these two plants, but the expansion of the Brazilian nuclear program, requires a future storage area for this type of reject. The storage of nuclear rejects also faces the resistance of civil societies, so that to define a suitable location for this purpose is a problematic issue.

Some countries, such as Japan, Sweden and France, whose energy matrix is preferably produced in thermonuclear plants, have researched and found some geological bodies that meet the metric required the installation of nuclear repositories (Neves et al., 2006, 2007; Silva and Tello, 2007). The geological survey, facing the
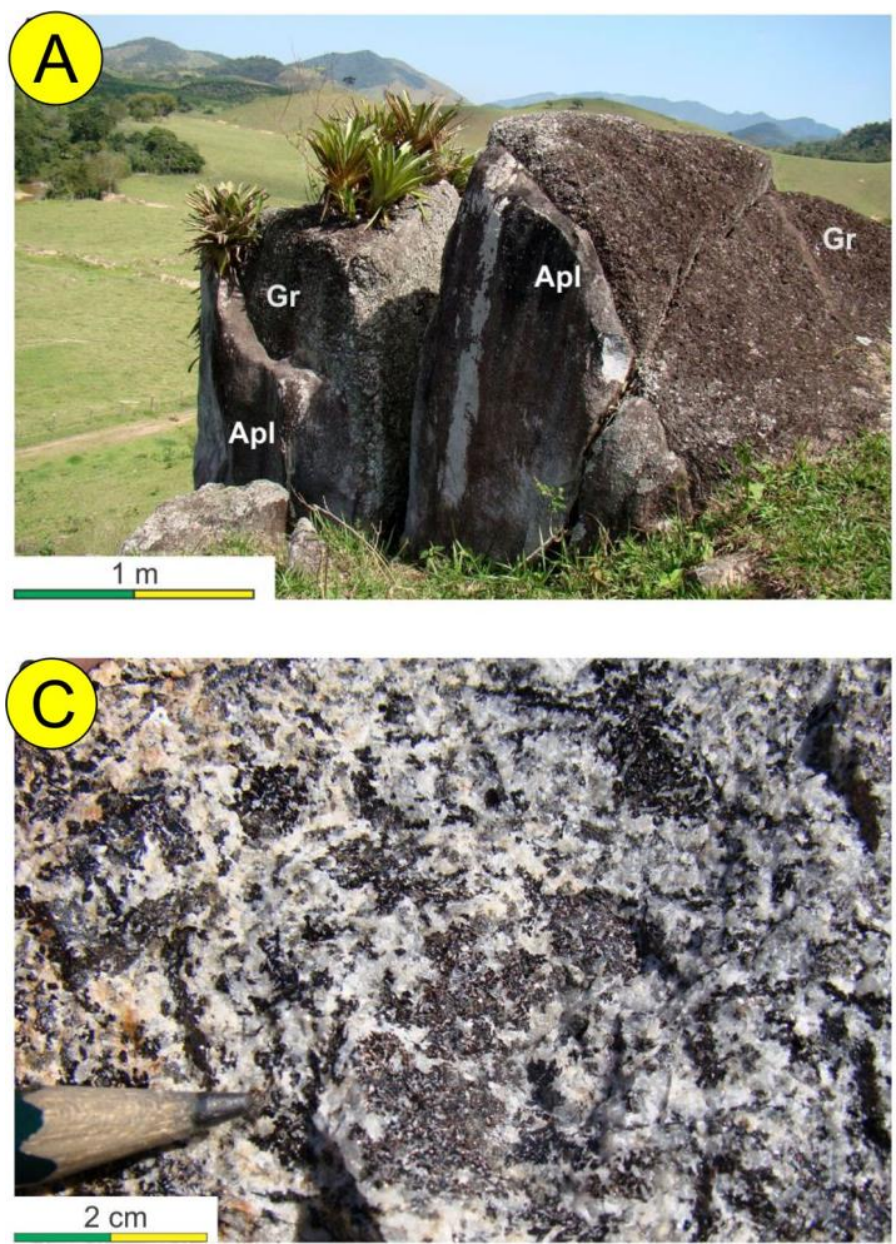

correlation with geophysical information aimed to delimit the gneissic host rocks of Ribeira Belt and to characterize their main compositional and textural variations, mainly mineralogical components, as well the structural features of rocks, in addition to how these features are distributed within the massif. These massifs have potential to be used as nuclear waste repositories. However, further detailed studies of the alkaline bodies, such as alkaline complexes here reported, may not only provide a scientific knowledge about the geological evolution and origin, but also to contribute with knowledge base enabling the future choice of geologic repository of radioactive waste.
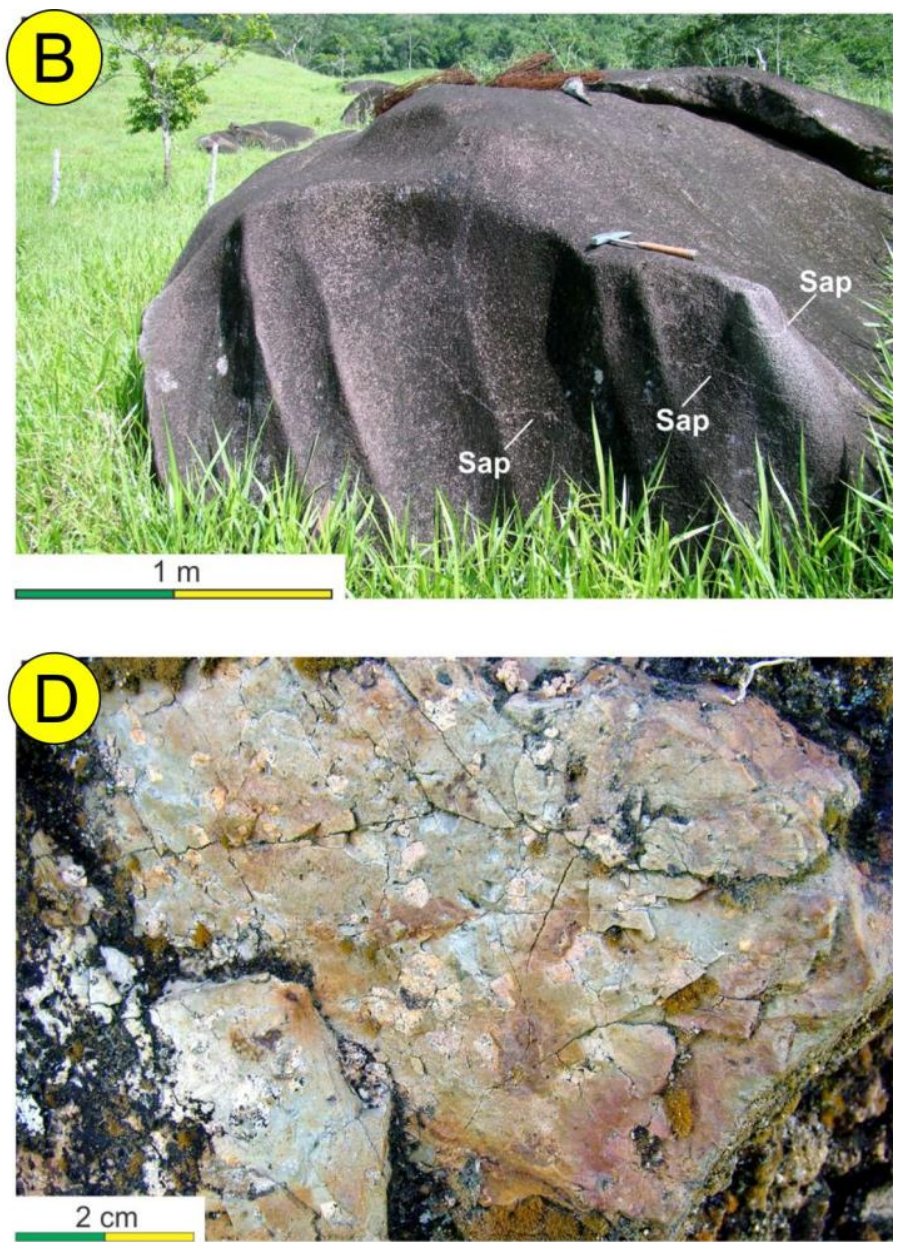

Fig. 15. The Rio Bonito alkaline rocks are composed of alkaline feldspar, clinopyroxene and amphibole, with magnetite and apatite as accessory minerals. (A) Alkalyne gabbroic rocks (Gr) cut by aplitic dykes (Apl) are observed. (B) with syenitic aplite (Sap). (C - D): details of Alkalyne gabbroic rocks and aplitic dykes, respectively. 


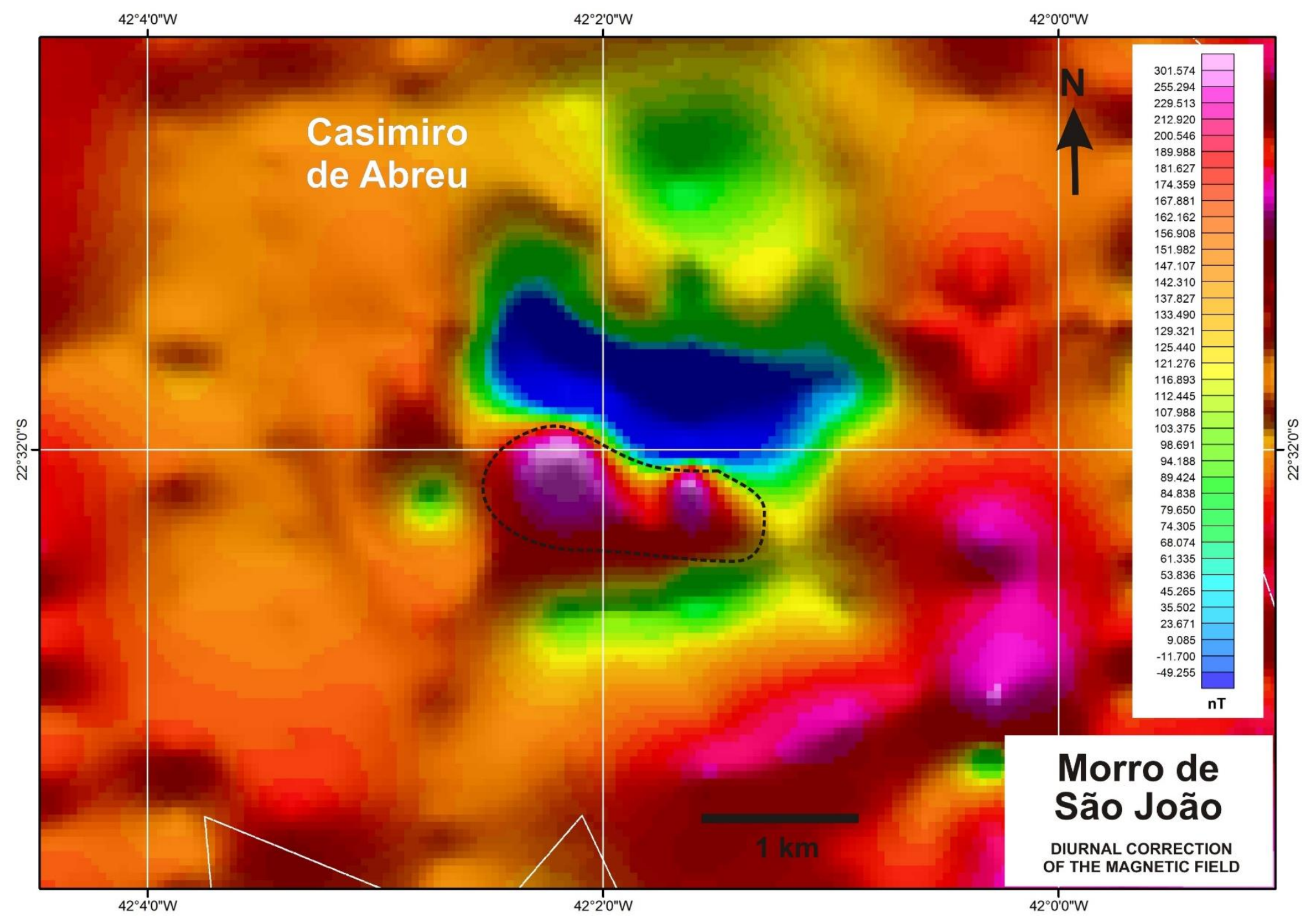

Fig. 16. Regional aeromagnetic features of Morro de São João alkaline intrusion. 

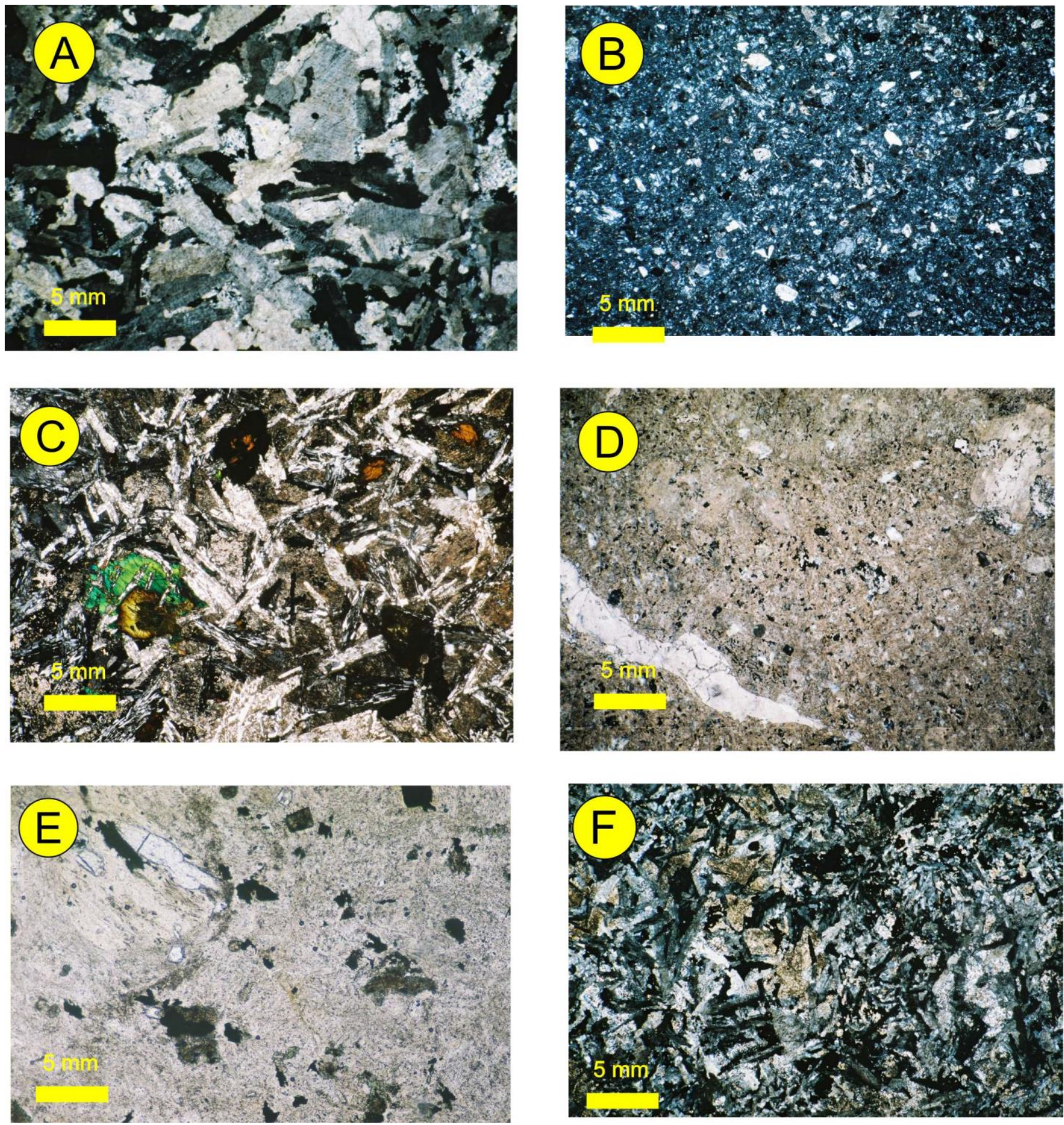

Fig. 17. The Morro de São João alkaline rocks comprises a non-saturated suite predominantly composed by tinguayte (A), trachyte (B, $\mathrm{C}$ and $\mathrm{D})$ and nefeline syenites (E and F). It presents mineralogical and textural variation showing syenitic, trachytic lavas and breccias intercalation. 


\section{Acknowledgments}

The authors would like to thank very much Financiadora de Estudos e Projetos - Finep, Fundação de Amparo à Pesquisa do Estado do Rio de Janeiro - FAPERJ and Conselho Nacional de Desenvolvimento Cientifico e Tecnologico - CNPq for the financial support necessary to built the infrastructure used for this research.

\section{References}

Almeida, F.F.M., 1976. The system of continental rifts bordering the Santos Basin. Anais da Academia Brasileira de Ciências, Rio de Janeiro, 48 (suplemento), 15-26.

Amaral., G., Bushee, J., Cordani, U.G., Kawashita, K., Reynolds, J.H., 1967. Potassium-argon ages of alkaline rocks from southern Brazil. Geochimica et Cosmochimica Acta 31, 117 142.

Brotzu, P., Beccaluva, L., Conte, A., Fonseca, M., Garbarino, C., Gomes, C.B., Leong, R., Macciotta, G., Mansur, R.L., Melluso, L., Morbidelli, L., Ruberti, E., Sigolo, J.B., Traversa, G., Valença, J.G., 1989. Petrological and geochemical studies of alkaline rocks from continental Brazil. The syenitic intrusion of Morro Redondo, RJ. Geochimica Brasiliensis 3, 63-80.

Brotzu, P., Melluso, L., Bennio, L., Gomes, C.B., Lustrino, M., Morbidelli, L., Morra, V., Ruberti, E., Tassinari, C., D’antonio, M., 2007. Petrogenesis of the Early Cenozoic potassic alkaline complex of Morro de São João, southeastern Brazil. Journal of South American Earth Sciences 24, 93-115. doi.org/10.1016/j.jsames.2007.02.006

CPRM - Companhia de Pesquisa de Recursos Minerais, 2000. Projeto Rio de Janeiro. Relatórios Técnicos. Brasília: CPRM Serviço Geológico do Brasil Departamento de Recursos Minerais - DRM - RJ.

Efremenkov, V.M., 1989. Radioactive waste management at nuclear power plants IAEA BULLETIN, 4/1989.

Ekren, E.B., Byers, F.M., 1976. Ash-flow fissure vent in westcentral Nevada. Geology 4 (4), 247-251,

Enokihara, C.T., 1983. O Armazenamento de Rejeitos Radioativos no Brasil, com Ênfase Especial em Rochas. Dissertação de Mestrado. IPEN, São Paulo.

Freire, C.B., Tello, C.C.O., 2007. Rejeitos e Gerência de Rejeitos Radioativos. Revista Brasileira de Pesquisa e Desenvolvimento 9, 43-49,

Freire, C.B., Tello, C.C.O., 2008. Study of Strontium Sorption in Brazilian Clays for their Use as a Barrier in Repository of Radioactive Wastes. Revista Brasileira de Pesquisa e Desenvolvimento 10, 1-5.

Geraldes, M.C., Motoki, A., Costa, A., Mota, C.E., Mohriak, W.U., 2013. Geochronology (Ar/Ar and K-Ar) of the South Atlantic post-break-up magmatism. Geological Society Special Publication 369, 1 - 34.

IAEA - International Atomic Energy Agency, 1977. Site Selection Factors for Repositories of Solid High-Level and Alpha Bearing Wastes in Geological Formations, Technical Report Series No. 177. Vienna.
IAEA - International Atomic Energy Agency, 1981. Underground Disposal of Radioactive Waste: Basic Guidance. Safety Series n 54. Vienna.

IAEA - International Atomic Energy Agency, 1983a. Criteria for Underground Disposal of Solid Radioactive Wastes. Safety Series $n^{\circ}$ 60. Vienna.

IAEA - International Atomic Energy Agency, 1983b. Concepts and Examples of Safety Analyses for Radioactive Waste Repositories in Continental Geological Formations. Safety Series $n^{\circ} 58$. Vienna.

IAEA - International Atomic Energy Agency, 1985. Performance Assessment for Underground Radioactive Waste Disposal Systems, Safety Series n 68. Vienna.

IAEA - International Atomic Energy Agency, 1989. Safety Principles and Technical Criteria for the Underground Disposal of High LeveI Radioactive Wastes, Safety Series $n^{\circ}$ 99. Vienna.

IAEA - International Atomic Energy Agency, 1994a. Classification of Radioactive Waste, Safety Series n ${ }^{\circ}$. lll-G-1.1. Vienna.

IAEA - International Atomic Energy Agency, 1994b. Siting of Geological Disposal Facilities, Safety Series $n^{\circ}$. 111-G-4.1. Vienna.

IAEA - International Atomic Energy Agency, 1995. The Principles of Radioactive Waste Management, Safety Series n ${ }^{\circ}$ 111- F. Vienna.

IAEA - International Atomic Energy Agency, 2000. Safety Requirements - Safety Standards Series - Predisposal Management of Radioactive Waste, Including Decommissioning. $n^{\circ}$. WS-R-2. Vienna.

IAEA - International Atomic Energy Agency, 2002. Issues relating to safety standards on the geological disposal of radioactive waste. TECDUC - 1282. Vienna.

IAEA - International Atomic Energy Agency, 2003. Scientific and Technical Basis for Geological Disposal of Radioactive Wastes, Technical Reports Series $n^{\circ} 413$. Vienna.

IAEA - International Atomic Energy Agency, 2009. Classification of Radioactive Waste, 2009 Edition. Vienna.

IAEA - International Atomic Energy Agency, 2011. Disposition of Radioactive Waste, 2011 Edition. Vienna.

Kano, K., Matuura, H., Yamauch, S., 1996. Miocene rhyolitic welded tuff infilling a funnel-shaped eruption conduit Shiotani, southeast of Matsue, SW Japan. Bulletin of Volcanology 59 (2), 125-135. doi.org/10.1007/s004450050

Martins, V.B., 2009. Metodologia Baseada em Sistemas de Informação Geográfica e Análise Multicritério para a Seleção de Áreas para a Construção de um Repositório para o Combustível Nuclear Usado. Programa de Engenharia Nuclear, UFRJ, COPPE. PhD Thesis.

Mota, C.E, Geraldes, M.C., 2006. A classificação de brechas magmáticas e sua implicação na evolução do Complexo Alcalino de Nova Iguaçu-RJ. Geociências (São Paulo) 25, 37 - 48.

Mota, C.E.M., Geraldes, M.C., Almeida, J.C.H., Vargas, T., Souza, D.M., Loureiro, R.O. e Silva, A.P., 2009. Características Isotópicas (Nd e Sr), Geoquímicas e Petrográficas da Intrusão 
Alcalina do Morro de São João: Implicações Geodinâmicas e sobre a Composição do Manto Sublitosférico. Geologia Série Cientifica da USP, v.9 n.1. doi.org/10.5327/Z1519874X2009000100006

Mota, C.E, Geraldes, M.C., Souza, M.A., Mane, M.A., 2012. Estrutura subsuperficial do Complexo Alcalino do Mendanha, Rio de Janeiro, por integração de dados geológicos e gravimétricos. REM. Revista Escola de Minas (Impresso) 65, 491-499.

Mota, C.E, Geraldes, M.C., Jourdan, F., 2014. ${ }^{40} \mathrm{Ar} /{ }^{39} \mathrm{Ar}$ age of Mendanha Alkaline Intrusion, Rio de Janeiro, Brazil. Comunicações Geológicas 101,157-161.

Motoki, A., 1979. Cretaceous volcanic vents in southeast part of Mt. Rokko, western Honshu, Japan. Bulletin of the Volcanological Society of Japan, Tokyo, 24 (2), 55-72,

Motoki, A., Sichel, S.E., Soares, R.S., Aires, J.R., Savi, D.C., Petrakis, G.H., Motoki, K.F., 2008. Vent-filling pyroclastic rocks of the Mendanha, the Itaúna, and the Cabo Frio Island, State of Rio de Janeiro, Brazil, and their formation process based of the conduit implosion model. Geociências, Rio Claro. 27 (3), 451-467.

Motoki, A., Sichel, S.E., Vargas, T., Aires, J.R., Iwanuch, W., Mello, S.L.M., Motoki, K.F., Silva, S., Balmant, A., Gonçalves, J., 2010. Geochemical evolution of the felsic alkaline rocks of Tanguá, Rio Bonito, and Itaúna intrusive bodies, State of Rio de Janeiro, Brazil. Geociências, Rio Claro 29 (3), 291-310.

Motoki, A., Vargas, T., Iwanuch, W., Sichel, S.E., Balmant, A., Aires, J.R., 2011.Tectonic breccia of the Cabo Frio area, State of Rio de Janeiro, Brazil, intruded by Early Cretaceous mafic dyke: Evidence of the Pan-African brittle tectonism? REMRevista Escola de Minas, Ouro Preto, 64 (1), 25-36.

Motoki, A., Geraldes, M.C., Iwanuch, W., Vargas, T., Motoki, K.F., Balmant, A., Ramos, M.N., 2012. The pyroclastic dyke and welded crystal tuff of the Morro dos Gatos alkaline complex, State of Rio de Janeiro, Brazil. REM. Revista Escola de Minas (Impresso), 65, 35 - 45.

Motoki, A., Vargas, T., Iwanuch, W., Balmant, A., Motoki, K. F., Geraldes, M.C., 2013a. Geology, Petrography and emplacement mode of the Morro dos Gatos alkaline intrusive complex, State of Rio de Janeiro, Brazil. Geociências (São Paulo. Impresso) 32, 1-15.

Motoki, A., Araujo, A.L., Sichel, S.E., Geraldes, M.C., Joudan, F., Motoki, K. F., Silva, S., 2013b. Nepheline syenite magma differentiation with crustal assimilation for the Cabo Frio
Island intrusive complex, State of Rio de Janeiro, Brazil. Geociências (São Paulo. Impresso) 32, 195-218.

Neves, J.M.C., Fuzikawa, K., Prates, S.P., Alves, J.V., Chaves, A.O., Brito, W., 2007. Safe Nuclear Waste Disposal: Geological and Hydrogeological Constraints. In: Simpósio Geologia do Sudeste, 2007, Diamantina, MG. Simpósio Geologia do Sudeste. Diamantina, MG: SBG, v. Anais.

Neves, J.M.C., Fuzikawa, K., Rios, F.J., Alves, J.V., Chaves, A.O., Brito, W., Prates, S.P., 2006.Condicionantes Geológicos e Geohidrológicos na Escolha de Local para um Repositório de Material Radioativo Usado. In: XLIII Congresso Brasileiro de Geologia, 2006, Aracaju. Boletim de Resumos do XLIII Congresso Brasileiro de Geologia. Salvador/Bahia: Sociedadade Brasileira de Geologia/ Núcleo da Bahia, 2006.

Petrakis, G.H., Motoki, A., Sichel, S.E., Zucco, L.L., Aires, J.R., Mello, S.L.M., 2010. Ore geology of special quality gravel and artificial sand: exemples of alkaline syenite of Nova Iguaçu, State of Rio de Janeiro, and rhyolite of Nova Prata, State of Rio Grande do Sul, Brazil. Geociências, Rio Claro, 29 (1), 21-32.

Raduan, R.N., 1994. Requisitos Ambientais para Disposição Final de Rejeitos Radioativos em Repositórios de Superfície. Dissertação de Mestrado. IPEN (Instituto de Pesquisas Energéticas e Nucleares), São Paulo, 185 p.

Reedman, A.J., Park, K.H, Merriman R.J., KIM, S.E., 1987. Welded tuff infilling a volcanic vent at Weolseong, Republic of Korea. Bulletin of Volcanology 49 (3), 541-546.

Silva, F., Tello, C.C.O., 2007. Integrated Management System for Radioactive Waste Repository (SGI3R). In: 2007 International Nuclear Atlantic Conference - INAC Santos. 2007, Belo Horizonte: DISCMIDIA.

Silva, C., Heilbron, M.C.P.L, Heilbron Filho, P.F.L., 2015. Site Selection of a Geological Repository for the Safe Disposal of High-Level Waste in the State of Rio de Janeiro. Revista Internacional de Ciências 5, 83-105.

Ulbrich, H.H.G.J., Gomes, C.B., 1981. Alkaline Rocks from Continental Brazil. Earth-Science Reviews, 17, 135-154. doi.org/10.1016/0012-8252(81)90009-X

Wolff, J.A., Ellwood, B.B, Sachs, S.D., 1999. Anisotropy of magnetic susceptibility in welded tuffs: application to a weldedtuff dyke in the tertiary Trans-Pecos Texas volcanic province, USA. Bulletin of Volcanology 51 (4), 299-310. 